\title{
8. Sınıf Ingilizce Öğretim Programının Bağlam, Girdi, Süreç ve Ürün (CIPP) Modeline Göre Değerlendirilmesi
}

\author{
Dr. Öğr. Üyesi Mehmet Başaran \\ Gaziantep Üniversitesi-Türkiye \\ mehmetbasaran@outlook.com
}

\author{
Oğuzhan ilteriş Özdemir \\ Milli Eğitim Bakanlığı \\ bilgehaniltekin@gmail.com
}

\author{
Muhammed Salih Can \\ Milli Eğitim Bakanlığı \\ salih.dorian02@gmail.com
}

\begin{abstract}
Özet:
Bu araştırmanın temel amacı, 2018-2019 eğitim öğretim yulından itibaren yürütülmekte olan Ortaöğretim 8. Sınıf Ingilizce Öğretim Programı́nın Stufflebeam tarafindan ortaya koyulan Bağlam - Girdi - Süreç - Ürün (CIPP) Modeli kullanularak öğretmen görüşleri doğrultusunda değerlendirmedir. Çalışmada nitel araştırma modellerinden durum çalışması uygulanmıştır. Araştırmanın çalışma grubunu, amaçlı örnekleme yöntemlerinden ölçüt örnekleme yöntemi kullanılarak belirlenen Gaziantep ve Şırnak'ta görev yapan 8. sınıf Ingilizce öğretmenleri oluşturmaktadır. Nitel veriler, CIPP Model temel alınarak hazırlanan yapılandırılmış görüşme formları aracılığıyla toplanmıştır. Nitel verilerin analizinde betimsel analiz yöntemi kullanılmıştır. Bağlam değerlendirmeye ilişkin sonuçlar; öğretmenler, program amaçlarının dil becerisini geliştirmek ve sınava hazırlı olduğunu ifade etmişlerdir. Programda ise sınava hazırlamak amaç olarak belirtilmemiştir. Girdi değerlendirmeye ilişkin sonuçlar; öğretmenler için özellikle materyallere ilişkin görüşlerinin olumsuz olduğu ve birçok nedenden dolayı programın amaçlarını karşılama noktasında yetersiz olduğu görülmüştür. Süreç değerlendirmeye ilişkin sonuçlar; süreçte program yoğunluğu, sınıf ortamı, ders saatinin yetersizliği, öğrenci seviyesi farklılıları, derse yönelik önyargı gibi birtakım sorunların yaşandığı görülmüştür. Ürün değerlendirmeye ilişkin sonuçlar; programın amaçlanan hedeflere ulaşma noktasında yetersiz olduğu ancak kelime bilgisine katkı sağladığı ortaya çıkmıştır. Araştırmanın sonuçlarına göre programın teoride revizesinin gerektiği uygulamada ortaya çımıştır.
\end{abstract}

Keywords: Ingilizce öğretim programı, CIPP Model, Program değerlendirme

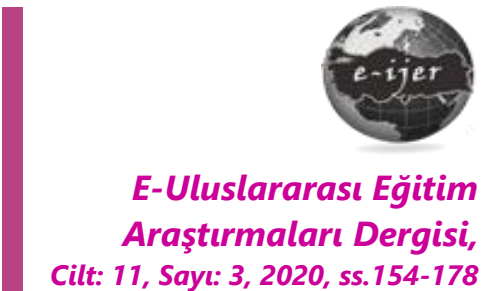

DOI: 10.19160/ijer.767692

Gönderim : 10.07.2020 Kabul : 18.11 .2020

\section{Önerilen Atıf}

Başaran, M. Özdemir, O.I.., \&. Can, M. S. (2020). 8. Sınıf İngilizce Öğretim Programının Bağlam, Girdi, Süreç ve Ürün (CIPP) Modeline Göre Değerlendirilmesi, E-Uluslararası Eğitim Araştırmaları Dergisi, Cilt: 11, Sayı: 3, 2020, ss. 154-178, DOI: 10.19160/ijer.767692 


\section{GiRiş}

Teknolojik ilerlemeler günümüzde, insanlar arasında daha yakın ilişkiler kurulmasını sağlamış, çeşitli ülkelerden insanlar kitle iletişim araçları sayesinde birbiri ile yakınlaşmış ve politik, kültürel, ticari ilişkiler giderek artmıştır. Bu sebeplerden dolayı dil öğretimi tüm insanlık için önemli bir gereksinim haline gelmiştir (Saracaloğlu, 1995). Demirel (2005)'in de belirttiği gibi dil konusunda çeşitlilik ve varsıllık içinde olan Avrupa'da yaşayan yurttaşların en az 3 dili bilmeleri ve bu dilleri de günlük yaşamda kullanabilmeleri günümüzde beklenen bir durum haline gelmiştir. Günümüz dünyasında yabancı dil demek, başka milletlerin teknolojilerini, sanatlarını, bilimlerini ve kültürlerini tanıma olanağı bulmak, anlamına gelmektedir. Bu nedenlerden dolayı farklı ülkelerle iletişim kurabilmek ve yenilikleri izleyebilmek için en az bir dil bilmek ve kullanmak gerekliliğin ötesinde şart haline gelmiştir. Dünya üzerinde farkı ülkelerde en çok kullanılan dil olmasının yanında refah seviyesi yüksek ülkelerin geliştirdikleri teknoloji ve dünya genelinde yapılan bilimsel çalışmalarının önemli bir kısmının İngilizce yazılması nedeniyle, günümüz dünyasında bilgiye erişebilmek adına İngilizce en önemli iletişim dili durumuna gelmiştir (Broghton, Brumfit, Flavell, Hill, \& Pincas, 2003).

İngilizce Öğretim Programı, Türk Milli Eğitimi'nin genel hedefleri doğrultusunda yeniden düzenlenmiştir. Türkiye'deki ilköğretim ve ortaöğretim öğrencilerine yüksek ve kaliteli İngilizce dil eğitimi sağlayabilmek amacıyla güncel bir müfredatın devamlılı̆ı için derslerin devamlı olarak gözden geçirilmesi gerekmektedir. Öğrencilerin, dil öğrencisi olmaktan çok dil kullanıcısı olmalarını sağlayabilmek için her türden sınıf etkileşimlerinde İngilizcenin kullanımı vurgulanmakta ve iletişimsel yeterliliğe özen gösterilmektedir. Türkiye'de belirlenen 8 . Sınıf Öğretim Programı, Avrupa Dilleri İçin Ortak Başvuru Metni'nde belirlenmiş olan seviyelerden A2 seviyesine denk gelmektedir. Bu seviye grubundaki öğrenciler için ilk olarak ilerleme kaydedilmesi istenilen yetenekler dinleme ve konuşma, bunların ilerletilmesinin ardından da okuma ve yazma yeteneklerinde ilerleme kaydedilmesidir. 7.sınıf öğretim programında görüldüğü gibi, 8. sınıf öğretim programında da genel öğrenme amacı olarak Avrupa Dilleri Için Ortak Başvuru Metni'nde yer alan A2 düzeyi için kazanımlar oluşturulmuştur. Buradan yola çıkılarak 8. Sınıf İngilizce Öğretim Programı́nın uygulanması durumunda öğrencilerin ulaşması istenilen kazanımlar; sözlü anlatım, dinleme-anlama, sözlü etkileşim, okuma-anlama, yazma becerileridir (MEB, 2018).

Alanyazında, program değerlendirmenin çok sayıda tanımı bulunmaktadır. Bu alanda kuram geliştiren kişilerin yaklaşımlarındaki farklılıklardan dolayı program değerlendirme tanımları da farklılık göstermektedir. Program değerlendirme, amaçları ortaya koyulmuş bir programın bu amaçlarına ne denli ulaşıldığını veya ulaşılamadığını kontrol etme ve raporlama sürecidir denilebilir. Program değerlendirme gözlem yoluyla ve ölçme araçları ile eğitim programının ne denli etkili olduğu ile ilgili veri toplama ve toplanan bu verileri programın ne denli etkili olduğunun belirtisi olan ölçütler ile karşılaştırarak yorumlama ve programın etkililiğe ile ilgili yargıya varma sürecidir (Erden, 1998).

Program değerlendirme yaparken programın belirtilen amaçlara ne derece ulaşabildiği eğer ulaşılmadıysa programda ne gibi eksik ve aksaklıklar olduğu bulunmaya çalışır. Eğer bir programın değerlendirilmesi yapılacak ise muhakkak bir program değerlendirme yaklaşımına ve modeline dayandırılması gereklidir. Program değerlendirme yapılacağı zaman uygun model ve yaklaşımın seçimi önem taşır. Çünkü uygun model seçilmezse bir uyumsuzluk ortaya çıkar. Şayet program değerlendirme sırasında kullanılan değerlendirme modeli ile seçilen program modeli arasında uyum yok ise bu iki model arasında uyumsuzluk ve çarpıklık ile karşılaşılır (Kelly, 2004).

Program değerlendirme yaklaşımları ve modelleri her zaman aynı odak noktasına sahip değildir. Bu konuda farklı yaklaşımlar bulunmaktadır. Bu araştırmada, 2018 yılında kabul edilen 
ve 2018-2019 eğitim öğretim yılından itibaren uygulamaya koyulan 8.sınıf İngilizce Öğretim Programı'nın Yönetim Yönelimli Değerlendirme Yaklaşımları içinde yer alan Stufflebeam'in Bağlam-Girdi-Süreç-Ürün (CIPP) Modeli'ne göre öğretmen görüşleri açısından değerlendirme tercih edilmiştir.

CIPP modeli, Daniel Stufflebeam tarafından 1960'ların sonlarına doğru ABD'de bulunan çeşitli kademelerdeki okulların programlarını iyileştirmek ve buna ek olarak öğrencilerde sorumluluk bilincini geliştirmek ve bu bilinci kazandırmak için geliştirilmiștir. Yalnızca eğitim kurumları ile kalmayıp başka kurumlara da uyarlanarak sosyal yardım programlarında, ticaret, sağlık alanında, inşaat ve askeri alanlarda da kullanılmıştır. Ayrıca personelin, programların, ürünlerin, kurumların, projelerin ve sistemlerin biçimlendirici ve toplam değerlendirmelerinde de kullanılmıştır. Stufflebeam tarafından geliştirilen bu modelin oldukça geniş kapsamlı bir model olduğu söylenebilir (Stufflebeam, 2003).

Adını "Bağlam (context), Girdi (input), Süreç (process) ve Ürün (product)" sözcüklerinin ilk harflerinden alan CIPP modeli oldukça kapsamlı ve çok yönlü bir model olduğu söylenilebilir (Robinson, 2002). Demirel (2005), CIPP modelini oluşturan bu dört aşamayı şöyle açıklamaktadır;

Bağlamın değerlendirilmesi aşamasında, program ile ilgili tüm etkenler ve mevcut durum incelenir. Bu adımdaki amaç hedeflerin belirlenmesine temel olacak bilgileri toplamak ve hedefleri belirlemektir. Giderilemeyen gereksinimler, kaçırılmış fırsatlar ve gereksinimlerin neden karşılanmadığı bu adımın analizi sırasında açıklanmaya çalışııı.

Girdinin değerlendirilmesi aşamasında, programın amaçlarına ulaşabilmek adına gereken tüm kaynaklar derlenir. Girdinin değerlendirilmesi adımında, bağlamın değerlendirilmesinin tersine, program ve öğeleri ayrıntılı biçimde analiz edilir. "Amaçlar mevcut duruma uygun olarak belirlenmiş mi? Öğretim stratejileri hedeflere uygun mu?" gibi programdaki çeşitli öğeler ile ilgili sorulara yanıt aranır.

Sürecin değerlendirilmesi aşamasında, programın uygulamasıyla ilgili yargıya varmak gereklidir. Sürecin değerlendirilmesi adımında, programın uygulanması sırasında gerçekleştirilen ve planlanan ile gerçek etkinlikler arasındaki uyuma bakılır.

Ürünün değerlendirmesi aşamasında, programın ürünü ile ilgili veri toplanır, bu adımda amaç beklenen ürün ile gerçek ürünün karşılaştııılmasıdır. Bu değerlendirme adımı, uygulanmakta olan programa devam edilip edilmeyeceği ya da nasıl değişikliğe gidilmesi gerektiği konusunda bilgi verir.

Giderek daha fazla küreselleşen, sınırların önemini yitirdiği günümüz dünyasında Ingilizce bilmemek öğrenciler için bir soruna dönüşmektedir. Türkiye'de İngilizce eğitimi ile ilgili birçok çalışma yapııırken, istenilen başarıya ulaşılamadığı görülmektedir. Yücel, Dimici, Yıldız ve Bümen (2017) tarafından yapılan çalışmada İngilizce eğitiminde uzun yıllardır tüm sınıf düzeylerinde yapılmış olan iyileştirme çalışmalarına karşın istenen düzeyde başarının henüz elde edilemediği açıkça belirtilmiştir. Alanyazın incelendiğinde istenilen başarının sağlanamamasın da farklı nedenlere ulaşıldığı görülmüştür. Yabancı dil öğretiminde karşılaşılan ilgi, gereksinim ve sorunların materyal yetersizliği, öğrencilerin motivasyon eksikliği, öğretmenlerin ise yeterli düzeye ya da sayıya sahip olmamasından kaynaklandığı düşünülmektedir (Peker, 2006).

Bu araştırma aracılığıyla öğrencilerin, ortaöğretim seviyesine geçişindeki son basamak olan 8.sınıf seviyesinde İngilizce yeterliklerinin neler olduğu, Liseye Geçiş Sınavı (LGS)'na hazırlıkı olup olmadıkları, öğrencilerin öğrendikleri bilgileri günlük yaşamda kullanıp kullanmadıkları ve öğrencilerin dönem içinde İngilizce dersine yönelik gösterdikleri gelişimin ne durumda olduğu, sorularına yanıt aranarak Türkiye'de İngilizce eğitimi (8.sınıf) açısından sorunları ve çözümleri ortaya konulması beklenmektedir. Araştırmanın, 8. sınıf İngilizce eğitim programı konusundaki sorunlar ve çözümleri, öğretmen görüşleri açısından ortaya konularak alanyazına katkı sağlayacağı da düşünülmektedir. Bu genel amaç çerçevesinde aşağıdaki sorulara yanıt aranmıştır. 
- Araştırmanın bağlam boyutunda, programın amaçları ve hedeflerini belirlemeye yönelik İngilizce öğretmenlerinin görüşleri nelerdir?

- Araştırmanın girdi boyutunda, programın amaçlarına ulaşmak için gerekli kaynakların neler olduğuna yönelik İngilizce öğretmenlerinin görüşleri nelerdir?

- Araştırmanın süreç boyutunda, programın uygulanması sırasında gerçekleştirilen ve planlanan etkinlikler ile gerçekte olan etkinliklere yönelik İngilizce öğretmenlerinin görüşleri nelerdir?

- Araştırmanın ürün boyutunda, programın hedeflerine uygun çıktılara yönelik İngilizce öğretmenlerinin görüşleri nelerdir?

\section{YÖNTEM}

\section{Araştırma Deseni:}

Bu araştırmada, İngilizce öğretmenlerinin 8. Sınıf İngilizce Öğretim Programı ile ilgili görüşlerini Bağlam- Girdi- Süreç- Ürün (CIPP) Modeli temel alınarak inceleyen nitel araştırma modeli kullanılmıştır. Nitel araştırma, nitel veri toplama araçlarının görüşme, gözlem ve doküman incelemesinin kullanıldığı algıların ve olayların hem eksiksiz hem de realist bir şekilde ortaya konulmasına yönelik çalışmalardır. Farklı bir söyleyişle nitel araştırma, kuram oluşturmayı hedefleyen bir bakış açısıyla sosyal olguları içinde bulundukları çevre içinde araştırmayı ve sosyal olguları anlamayı ön plana alan bir yöntemdir (Yıldırım \& Şimşek, 2018). Nitel araştırma, Akman (2014)'a göre nitel veri toplama yöntemleri aracılığıyla olayların bulunduğu ortamda gerçekçi ve bütünsel bir şekilde belirlemeyi amaçlayan bir araştırmadır. Amaçlanan asıl durumun genelleme olmadığı nitel ölçme yöntemlerinin kullanıldığı kavram ve kuram oluşturmayı amaçlayan modellerdir. Araştırmada, 10 İngilizce öğretmeninin 8. Sınıf İngilizce Öğretim Programı hakkında görüşleri ortaya konulduğu için araştırmanın deseni durum çalışması olarak belirlenmiştir. Durum çalışmalarında bazen bir bazen birden fazla olay, toplum, program, grup ya da sınırlandırılmış bir olgunun ayrıntılı incelenmesi söz konusudur. Durum çalışmalarında duruma bütünsel anlamda bakılmaktadır. Durum; yerine göre bir öğrenci, öğretmen, okul ya da yeni uygulanan bir programdan oluşabilmektedir. Durum analizi, aktüel bir olgunun gerçek bağlamı içinde irdelenmesine denilmektedir (Yin, 2003). Araştırmada incelenen durum ise 8. Sınıf İngilizce Öğretim Programı́na yönelik 8. Sınıf İngilizce öğretmenlerinin Stufflebeam'ın Bağlam- GirdiSüreç- Ürün (CIPP) Modeli temel alınarak görüşlerini incelemedir.

\section{Çalışma Grubu:}

Bu araştırmada, amaçlı örnekleme yöntemlerinden olan ölçüt örnekleme yöntemi kullanılmıştır. Bu örnekleme yönteminde çalışma grubu belirlenmeden önce çalışma grubunu belirlemeye yönelik ölçüt ya da ölçütler belirlenir (Yıldııım \& Şimşek, 2018). Nitel araştırmalara bakıldığında örneklemin büyüklüğünü belirlemek nicel araştırmalara kıyasla daha zordur, bu kısımda önemli olan araştırmanın amacına bakarak neyin bilinmesi istendiği ve elimizdeki zaman ile kaynaklar sayesinde nelerin yapılması istendiğidir (Büyüköztürk, Çakmak, Akgün, Karadeniz, \& Demirel, 2010). Araştırmanın çalışma grubunu Gaziantep ve Şırnak'ta Milli Eğitim Bakanlığına bağlı okullarda en az iki yıl görev yapmış 8. sınıf derslerine giren 10 İngilizce öğretmeni oluşturmaktadır. Bu çalışma grubunun seçilmesi araştırmacıların önceden belirlemiş olduğu ölçütlere uygun çalışma grubu olmasıdır. Araştırmada yer alan çalışma grubunun demografik özellikleri aşağıda yer alan Tablo 1'de sunulmuştur. 
Tablo 1. Katılımıcılara ait demografik bilgiler

\begin{tabular}{llll}
\hline Görüşmeciler & Kıdem Yılı & Görev Yeri & Mezuniyet \\
\hline K1 & 2 & Gaziantep & Ingilizce Öğretmenliği \\
K2 & 4 & Gaziantep & Ingilizce Öğretmenliği \\
K3 & 7 & Gaziantep & Ingilizce Öğretmenliği \\
K4 & 2 & Gaziantep & Ingilizce Öğretmenliği \\
K5 & 2 & Gaziantep & Ingilizce Öğretmenliği \\
E6 & 7 & Gaziantep & Ingiliz Dili ve Edebiyatı \\
K7 & 5 & Şırnak & Ingiliz Dili ve Edebiyatı \\
E8 & 4 & Şrnak & Ingilizce Öğretmenliği \\
E9 & 2 & Şırnak & Ingilizce Öğretmenliği \\
E10 & 2 & Şırnak & Ingilizce Öğretmenliği \\
\hline
\end{tabular}

Araştırmaya dördü erkek ve altısı kadın olmak üzere toplam 10 İngilizce öğretmeni katılmıştır. Görüşmecilerin mesleki tecrübesi iki ile yedi yıl arasında değişmektedir. Bu görüşmecilerden altısı Gaziantep'te, dördü Şırnak'ta bulunan devlet okullarında görev yapmaktadır.

\section{Veri Toplama Aracı:}

Araştırmalarda genellikle tercih edilen nitel veri toplama araçlarından biri olan görüşme; önceden hazırlanan soruların sorulduğu ve katıımcı kişi veya kişilerin sorulan sorulara yanıtlar verdiği hedefi olan bir söyleşidir (Kuş, 2003). Araştırmada veri toplama aracı Stufflebeam'ın Bağlam- Girdi- Süreç- Ürün (CIPP) Modeli temel alınarak araştırmacılar tarafından geliştirilen ve açık uçlu sorulardan oluşan yapılandırılmış görüşme formudur. Formun hazırlanmasında ilgili alanyazın taranmış elde edilen bilgilerden yola çıkılarak görüşme soruları ortaya çıkarılmıştır. Bu sorular bir araya getirilerek "Yapılandırılmış Görüşme Formu" oluşturulmuştur. Yapılandırılmış görüşme formuna yönelik olarak uzman görüşü alınmış ve yapılan öneriler doğrultusunda bazı sorular yeniden düzenlenmiş, bazı sorular ise çıkarılmıştır. Yapılandırıımış görüşme tekniği ele alındığında araştırma katılımcılarının görüşünü belirli başlıklara göre cevapladığı anket çalışmalarına ya da tutum ölçeklerine benzemektedir (Robson, 1993). Araştırma yapılırken söz konusu araştırmaya katııımcı olan her bir bireye aynı sorular yöneltilmeli, sorular aynı biçimde sorulmalı ve aynı sözcüklerle sorulmalıdır (Türnüklü, 2000).

\section{Veri Toplama Süreci:}

Nitel araştırmada elde edilen veriler, nicel araştırmalarda olduğu gibi salt sayılarla açıklanamaz. Nitel araştırmadaki temel amaç sayılardan yola çıkarak sonuçlara ulaşmak değildir. Asıl amaç, konuya yönelik okuyucuya gerçekçi ve bütünsel bir resim ortaya çıkarmaktır (Yıldırım \& Şimşek, 2018). Verilerin toplanma sürecini araştırmacının açıklaması tutarlılık ve inanııırık gibi ilkeler için önemli bir etken sayılabilir (Kapcak \& Okuyan, 2016). Araştırmanın uygulanması için öncelikle 8.sınıf İngilizce derslerine giren öğretmenlerle iletişime geçilerek araştırmanın amacı, uygulanışı ve uygulama süresi ile ilgili bilgilendirme çalışması yapılmıştır. Öğretmenlere 8.Sınıf Ingilizce Öğretim Programı fikir verme açısından ulaştııılmıştır. Araştırma verilerinin toplanmasında yapılandırılmış görüşme tekniğinden yararlanılmıştır. Bu görüşme türünün tercih edilmesinde, katılımcı sayısının az oluşu, görüşme esnasında katılımcının düşüncelerini samimi bir şekilde aktarabilmesi etkili olmuştur. Araştırma verileri 02.05.2020- 07.05 .2020 arasında, katılımcılarla planlanan saatlerde toplanmıştır. Daha sonra katılımcılarla yapılan telefon konuşmaları ve görüntülü konuşmalar, yaklaşık olarak 13 dakika ile 34 dakika arası sürmüştür. Görüşmeler her katılımcı için tek oturumda gerçekleşmiştir. Veriler ses kaydı alınarak ve formlara yazılarak desteklenmiştir. Erkek öğretmenler (E), kadın öğretmenler (K), öğretmen sıra numarası $1,2,3 \ldots$ şeklinde belirlenmiştir. 


\section{Veri Analizi:}

Araştırmada betimsel analiz yapılarak veriler elde edilmiştir. Araştırmada görüşme, veri toplama aracı olarak kullanılmıştır. Görüşmede katılımcılara önceden belirlenen temalara göre açık uçlu sorular yönlendirilmiştir. Sorulara verilen cevaplardan kodlar çıkartılmıştır. Betimsel analizde önceden belirlenen temalara göre veriler toplanmaktadır. Hatta bu temalara göre sorular da oluşturulabilmektedir (Yıldırım \& Şimşek, 2005). Araştırmada elde edilen verilerin analizi için araştırmacılar tarafından ilk aşama olarak ses kayıtlarının dökümü yapılmış ve veriler hazırlanan formlara dönüştürülmüştür. Dökümlerin doğruluğu ve geçerliği için araştırmacılar tarafından ikinci kez ses kayıtları dinlenilerek elde edilen dökümlerin doğruluğu kontrol edilmiştir.

Elde edilen veriler, araştırmacılar tarafından farklı zamanlarda analiz edilmiştir. Bu analiz doğrultusunda araştırmacılar tarafından farklı kodlar çıkartılmıştır. Araştırmacılar yapmıs oldukları analizleri daha sonra karşılaştırarak görüş birliğine varılan ve varılamayan noktaları belirlemişlerdir. Araştırmacılar analizlerine son şeklini vermelerinde Miles ve Huberman (1994) tarafından ortaya koyulan "Güvenirlik=Görüş birliği/Görüş Ayrılığı+Görüş Birliği x 100" formülünü kullanmışlardır. Araştırmacılar arasında uyum güvenirliği 82 olarak bulunmuştur. Bulunan bu güvenirlik değeri bilimsel çalışmalar için kabul edilebilir düzeyde sayılmaktadır (Miles \& Huberman, 1994). Verilerin analizinde önceden belirlenen temalar ve verilerden elde edilen kodlar okuyucuların anlamasını kolaylaştırmak amacıyla tablolaştııılmıştır.

\section{Geçerlik ve Güvenirlik:}

Araştırmalarda geçerlik ve güvenirlik nitel araştırmalarda, nicel araştırmalarda daha farkı olarak ele alınmaktadır (Yıldııım \& Şimşek, 2018). Nicel araştırmalarda geçerlik ve güvenirlik kavramlarının daha çok kullanılmasına karşın nitel araştırmalarda inanılıılık, ulaşılan bulguların doğruluğu ve araştırmayı yapan kişi veya kişilerin ne derece yetkin olduğu gibi ifadeler daha çok kullanılmaktadır (Krefting, 1991).

Çalışmanın inanılırlığını sağlamak için, alanında uzman görüşüne başvurulmuştur. Aynı zamanda iki araştırmacının verilerin toplanması, analizi ve yorumlanmasında yer almasıyla araştırmacı üçlemesi sağlanmıştır. Araştırmanın güvenirliğini artırmak için katılımcılar, gönüllü İngilizce öğretmenlerden seçilmiştir. Araştırmanın doğrulanabilirliği için ham veriler, yorum ve öneriler kayıt altına alınarak dokümanların araştırmacılar tarafından tekrar incelenmesi sağlanmıştır. Gerekli durumlarda görüşme esnasında katılımcılara araştırmanın kapsamı doğrultusunda bazı yönlendirmeler yapılmıştır. Araştırmanın geçerliliğini sağlamak için, katıımcı teyidi, araştırmacı üçlemesi, katılımcıların tanıtımı ve araştırmacının önyargılarından uzak durması gibi tekniklere başvurulmuştur. Çalışma grubundaki kişilerin isimleri belirtilmemiştir. Araştırmanın güvenirliğinin sağlanması için görüşme formunda yer alan soruların hazırlanmasında ve verilerin nasıl analiz edileceğine yönelik uzman görüşüne başvurulmuştur. Verilerin analiz kısmında yanlış anlamaların ve ön yargıların önlemek için veriler araştırmacılar tarafından yeniden gözden geçirilmiştir. Verilerin analizini yapan araştırmacıların nitel çalışmalar dersini yüksek lisans sürecinde aldıklarından dolayı bu konuda deneyimli olmaları bu çalışmanın güvenirliğini doğrudan arttırdığı söylenebilir. Araştırmanın veri analizi sürecinde alanında uzman bağımsız araştırmacının görüşleri de alınmıştır.

\section{BULGULAR VE YORUM}

Bu bölümde öğretmenlerle yapılan yapılandırılmış görüşmeler neticesinde, kullanılan betimsel analiz sonuçlarına göre veriler, toplam 28 tema altında toplanmıştır. Belirlenen temalar ve öğretmen görüşlerinden elde edilen veriler, tema-kod çerçevesinde yorumlanmıştır. Tema-kodlar incelendiğinde, öğretmenlerin bağlam boyutunda 8 , girdi boyutunda 8 , süreç boyutunda 4 ve 
ürün boyutunda 8 tema olduğu görülmektedir. Her bir boyutla ilgili tema ve kodlar ayrıntılı olarak araştırmada incelenmiştir.

\section{1-Bağlam Değerlendirmeye iliş̧kin Bulgular}

Araştırmanın bağlam aşamasına ilişkin öğretmen görüşleri incelendiğinde programın amaçları, hedeflerin belirlenmesi ile ilgili sorulara yanıt aranmış ve bağlam boyutuna dair sorulan 6 soru neticesinde kodlara ulaşılmıştır, kodlar önceden belirlenen temalara yerleştirilmiştir. Bu temalar: "Programın amacı, program ihtiyaçları, programın beğenilen yönleri, programın beğenilmeyen yönleri, sınava yönelik ihtiyaç, dil becerisi ihtiyacı, içerik uygunluğu ve 8.sınıfa uygunluk." Elde edilen kodlar ve temalara bakarak 10 öğretmenin bağlam değerlendirmeye yönelik görüşleri şu şekildedir.

Tablo 2. Bağlam boyutundaki 1. soruya ilişkin tema ve kodlar

\begin{tabular}{llc}
\hline Tema & Kod & Frekans(s) \\
\hline \multirow{3}{*}{ Programın Amacı } & Dört temel beceri & $(3)$ \\
& Sınava hazırlamak & $(8)$ \\
& A2 seviyesini geliştirme & $(6)$ \\
\hline
\end{tabular}

Bağlam boyutundaki ilk soru olan: "Sizce 8. sınıf İngilizce öğretim programının amacı nedir?" kısmında "programın amacı" teması oluşturulmuştur. Verilerden elde edilen kodlar: "sınava hazırlamak, A2 seviyesini geliştirme ve 4 temel beceri" şeklindedir. Araştırmada yer alan öğretmenler bu soruya şu şekilde yanıtlar vermiş̧ir:

K1:"Ortaöğretimdeki öğretim programlarının hepsinin amacı dört temel beceriyi kazandırmaktır. Okuma, yazma, konuşma ve dinleme. Ancak 8. Sınıfta çocukların dil seviyeleri hala A2 düzeyinde. Avrupa çevresel programa göre; öğretim programının amacıysa 6 ve 7. Sınıflara kıyasla daha çok konuşma ve yazma üzerinedir. Yani çocukların üretici dil becerilerini geliştirmeye yöneliktir." (4 temel beceri, A2 seviyesini geliştirme)

K7: "Öğrencileri günlük hayatta konuşacakları Ingilizceye alıştırmak ve LGS'ye hazırlamaktır." (Sınava Hazırlamak, A2 seviyesini geliştirme)

Tablo 3. Bağlam boyutundaki 2. soruya ilişkin tema ve kodlar

\begin{tabular}{llc}
\hline Tema & Kod & Frekans(s) \\
\hline & Sınava verimli hazırlamak & $(2)$ \\
& A2 seviyesini geliştirme & $(3)$ \\
& Hayatilik ilkesine uygunluk & $(1)$ \\
Program Ihtiyaçları & Etkileşimli eğitim & $(4)$ \\
& 4 temel beceriyi geliştirme & $(4)$ \\
& Öğrenciye uygunluk & $(3)$ \\
& Bilgiyi artırma & $(2)$ \\
\hline
\end{tabular}

Bağlam boyutundaki ikinci soru olan "ihtiyaçları karşılamak için sizce öğretim programının amaçları ne olmalıdır?" kısmında "program intiyaçları" teması oluşturulmuştur. Verilerden elde edilen kodlar: "sınava verimli hazırlamak, A2 seviyesini geliştirme, 4 temel beceriyi geliştirme, bilgiyi arttırma, hayatilik ilkesine uygunluk, etkileşimli eğitim" şeklindedir. Araştırmada yer alan öğretmenler bu soruya şu şekilde yanıtlar vermiştir:

K3: "8. Sınıf açııından bakacak olursak amacımız dört dil becerisini kaliteli bir şekilde kullanabilen çocuklar yetiştirmek olmalıdır." (4 temel beceriyi geliştirme)

E9: "Ülkemizde iş bulma; daha iyi bir lise, daha iyi bir üniversiteye bağlı olduğu için ihtiyaçları karşılamak adına programın öğrencileri sınavlara daha iyi hazırlayacak bir amaca sahip olması gerektiğini düşünüyorum." (Sınava verimli hazırlamak) 
Tablo 4. Bağlam boyutundaki 3. soruya ilişkin tema ve kodlar

\begin{tabular}{llc}
\hline Tema & Kod & Frekans(s) \\
\hline & Programın sadeliği & $(3)$ \\
& Hayatilik ilkesine uygunluk & $(4)$ \\
& Kitap içeriği & $(2)$ \\
Programın Beğenilen Yönleri & 4 temel beceri & $(2)$ \\
& Değerler eğitimi & $(4)$ \\
& Seviye uygunluğu & $(2)$ \\
\hline \multirow{3}{*}{ Programın Beğenilmeyen Yönleri } & Gelenekselci yaklaşım & $(1)$ \\
& Uygulama yetersizliği & $(4)$ \\
& Dil edinme yetersizliği & $(3)$ \\
& Seviye uygunsuzluğu & $(3)$ \\
& Ders saati yetersizliği & $(2)$ \\
& Program yoğunluğu & $(3)$ \\
\hline
\end{tabular}

Bağlam boyutundaki üçüncü soru olan "Programla ilgili en beğendiğiniz ve beğenmediğiniz yönler nelerdir?" kısmında 2 tema oluşturulmuştur. Bunlar "programın beğenilen yönleri ve programın beğenilmeyen yönleri"dir. Programın beğenilen yönleri temasından elde edilen kodlar: "4 temel beceri, değerler eğitimi, seviye uygunluğu, hayatilik ilkesine uygunluk, programın sadeliği, kitap içeriği, kelime bilgisi; programın beğenilmeyen yönleri temasından elde edilen kodlar: gelenekselci yaklaşım, uygulama yetersizliği, program yoğunluğu, seviye uygunsuzluğu, dil edinme yetersizliği ve ders saati yetersizliği" şeklindedir. Araştırmada yer alan öğretmenler bu soruya şu şekilde yanıtlar vermiştir:

K1: "Program aslında çok iyi. Hem dört temel dil becerisine yönelik, hem de milli ve manevi değerlerimizi ele alıyor. Mesela 8. Sinıf kitaplarında bayramlar ve festivallerden bahsediyor. Ayrıca her ünitenin başında bir tane özlü söz mevcut. Programın amaçları güzel ancak uygulanışı sıkıntılı diye düşünüyorum. Beğenmediğim yönü: geleneksel yöntem daha çok, 'benimle birlikte yap' ya da 'benden sonra tekrar et' ilkesine dayanıyor. Bu yöntemlerle yetişmiş ögrretmenin hala görevde olduğunu düşünelim, bir de yeni mezun olmuş birisinden bahsedelim. Ikisinin öğretim biçimi çok farklı oluyor. Bu yüzden ögretmenlerde sıkıntı var." (Hayatilik ilkesine uygunluk, 4 temel beceri, değerler eğitimi; gelenekselci yaklaşım, uygulama yetersizliği)

K4: "Programda beğendiğim yönler günlük hayata yönelik konuların yer alması yani Çocukların günlük hayatta kullanabilecekleri konuların yer alması ve yaş gruplarına göre uygun bir seviyede olması beğenmediğim yönü ise çok yoğun olması. "(Hayatilik ilkesine uygunluk, seviye uygunluğu; program yoğunluğu)

Tablo 5. Bağlam boyutundaki 4. soruya ilişkin tema ve kodlar

\begin{tabular}{llc}
\hline Tema & Kod & Frekans(s) \\
\hline \multirow{2}{*}{ Sınava Yönelik İhtiyaç } & Yeterli & $(6)$ \\
& Yetersiz & $(4)$ \\
\multirow{2}{*}{ Dil Becerisi İhtiyacı } & Yeterli & $(2)$ \\
& Yetersiz & $(8)$ \\
\hline
\end{tabular}

Bağlam boyutundaki dördüncü soru olan: "Program içeriği, ihtiyaçları ne ölçüde karşılamaktadır?" kısmında "sınava yönelik intiyaç ve dil becerisi ihtiyacı" temaları çıkarılmıştır. Sınava yönelik intiyaçları karşılamada 6 öğretmen yeterli, 4 öğretmen yetersiz; dil becerisi intiyacını karşılamada ise iki öğretmen yeterli, sekiz öğretmen yetersiz yanıtını vermiştir. Araştırmada yer alan öğretmenler bu soruya şu şekilde yanıtlar vermiştir:

K4: "Ihtiyaçları çok fazla karşıladığıı düşünmüyorum çünkü ögrrencilerin geçmiş yıllardan eksiklikleri var eksik ingilizce bilgileri ve önyargıları var ingilizcedeki bu 
eksiklikleri kapatmaya çalışlyoruz ama bunun için zaman ve materyal bulamıyoruz. " (Yetersiz)

K5: "Program içeriği yani şimdi sınava yönelik ihtiyaçları karşılayabilir ama şimdi iletişim kurmak için kullanacaksak eğer hiçbir şekilde karşılamıyor çok eksik. Genel olarak karşılamakta yetersiz kalıyor." (Yeterli; yetersiz)

Tablo 6. Bağlam boyutundaki 5. Soruya ilişkin öğretmen görüşlerinden elde edilen tema ve kodlar

\begin{tabular}{llc}
\hline Tema & Kod & Frekans(s) \\
\hline \multirow{2}{*}{ Içerik Uygunluğu } & Program-içerik uyumluluğu & (8) \\
\cline { 2 - 3 } & Program-içerik uyumsuzluğu & (2) \\
\hline
\end{tabular}

Bağlam boyutundaki beşinci soru olan "Ders kitaplarındaki içerik program hedeflerine uygun mudur?" kısmında "içerik uygunluğu" teması çıkarılmıştır. Bu soruda 6 öğretmen ders kitaplarındaki içeriğin program hedeflerine uyduğu, 4 öğretmen ise ders kitaplarındaki içeriğin program hedeflerine uymadığı yanıtını vermiştir. Araştırmada yer alan öğretmenler bu soruya şu şekilde yanıtlar vermiştir:

E8: "Uygundur. Çünkü ders kitabında bulunan 10 ünitenin yeterli zamanda öğrenciye kazandırılarak, geri dönüt alınabildiğini görüyoruz." (Program-içerik uyumluluğu)

Ders kitaplarındaki içeriğin program hedeflerine uymadığını belirten K1 kodlu öğretmenin cevabı aşağıda örnek olarak verilmiştir.

K1: "Ben Türkiye'de ders kitaplarının başarlı olduğunu düşünmüyorum. Bu kitapları yayınlayan kurum, köklü dil eğitimi kurumlarıyla hiçbir şekilde anlaşma yapmıyor. (Oxford, Cambridge gibi) Bu kitapları hazırlayanlar da ya öğretmenler ya da üniversitelerdeki hocalar oluyor. Bu yüzden ne görsel ne de işitsel olarak zenginleştirilmiş materyaller sunulamıyor. Çocuklar çok sıkılıyor, çünkü hep mekanik aktiviteler var. Dikkat çekici ya da ilgi çekici değil. Ders kitaplarındaki içerik programa hizmet etmiyor. Çocuk hayatla ne kadar yakın ilişki kurarsa, kalite o kadar artıyor. Buna yönelik geliştirmeler yapılmalı." (Program-içerik uyumsuzluğu)

Tablo 7. Bağlam boyutundaki 6. soruya ilişkin tema ve kodlar

\begin{tabular}{llc}
\hline Tema & Kod & Frekans(s) \\
\hline \multirow{2}{*}{ 8.Sınıfa Uygunluk } & Seviyeye uyma & (7) \\
& Seviyeye uymama & (3) \\
\hline
\end{tabular}

Bağlam boyutundaki altıncı soru olan: "Ders kitabındaki içerik LGS' ye hazırlanan 8. Sınıf öğrencilerinin seviyesine uygun mudur?" kısmında "8. Sınıfa uygunluk" teması çıkarılmıştır. Bu soruda 7 öğretmen seviyeye uygun; 3 öğretmen ise seviyeye uygun değil yanıtını vermiştir. Araştırmada yer alan öğretmenler bu soruya şu şekilde yanıtlar vermiştir:

K5: "Sekizler için uygun ancak biraz ağır bence basitleștirilmesi gerekiyor ancak yine sınav için yetersiz." (Seviyeye uyma)

Ders kitabındaki içeriğin seviyeye uygun olmadığını belirten öğretmenlerden K1 kodlu öğretmenin cevabı aşağıda örnek olarak verilmiştir.

K1: "Başlıklar çok güzel, her ünitenin başında ne öğrenileceği belirtilmiş. Beklentiler az çok tahmin edilebilir. Fakat şöyle ki; istanbul ya da Ankara'da bulunan bir öğrenci için uygun olabilirken, doğuda ya da istanbul Türkçesinden uzak coğrafyalarda uygun olmuyor. Çünkü zaten bu konumlarda öğretim daha zor. Mesela ben görev yaptığım şehir için uygun olmadığını düşünüyorum. Bir ünitede öğretilmesi gerekenden çok daha fazla kelime var. Dil bilgisi olarak da çok üzerinde durulmuş şeyler var. Yani biraz ortalamanın üzerinde." (Seviyeye uymama)

Araştırmanın bağlam boyutunda görüşmecilerin verdikleri yanıtlara ve yanıtlardan çıkarılan kodlara göre "program amacının sınava hazırlamak ve A2 seviyesini geliştirmek olduğu; program ihtiyaçlarının 4 temel beceriyi geliştirmek, etkileşimli eğitim sağlamak olduğu; programın beğenilen yönlerinin daha çok hayatilik ilkesine uygunluk ve programın sadeliği olduğu; programın beğenilmeyen yönlerinin daha çok uygulama yetersizliği ve program 
yoğunluğu olduğu; programın sınava yönelik ihtiyaçları karşılamada yeterli ancak dil becerisi intiyacı karşılamada yetersiz olduğu; program ve ders içeriğinin uyumluluğu; ders kitaplarındaki içeriğin seviyeye uygunluğu" ortaya çıkmıştır.

\section{2- Değerlendirmeye İlişkin Bulgular}

Araştırmanın girdi aşamasına ilişkin öğretmen görüşleri incelendiğinde programın amaçlarına ulaşmak için gerekli kaynaklar ile ilgili sorulara yanıt aranmış ve girdi boyutuna dair sorulan 5 soru neticesinde kodlara ulaşılmıştır. Kodlar önceden belirlenen temalara yerleştirilmiştir. Bu temalar: "hazırbulunuşluk, öğrenciye uygunluk, materyal etkisi, bireysel çalışma, toplu çalışma, ek çalışmalar, görsel-işitsel araçlar ve basılı-yazılı araçlar"dır. Elde edilen kodlar ve temalara bakarak 10 öğretmenin girdi değerlendirmeye yönelik görüşleri şu şekildedir.

Tablo 8. Girdi boyutundaki 1. soruya ilişkin tema ve kodlar

\begin{tabular}{llc}
\hline Tema & Kod & Frekans(s) \\
\hline Hazırbulunuşluk & Yeterli & $(1)$ \\
& Yetersiz & $(9)$ \\
\hline
\end{tabular}

Girdi boyutundaki ilk soru olan "Öğrencilerin program için hazırbulunuşluk seviyesi ne düzeydedir?" kısmında "hazırbulunuşluk" teması çıkarılmıştır. Bu soruda 9 öğretmen öğrencilerin hazırbulunuşluk seviyesini "yetersiz" bulmuştur; sadece 1 öğretmen hazırbulunuşluk seviyesini "yeterli" bulmuştur. Araştırmada yer alan öğretmenler bu soruya şu şekilde yanıtlar vermiştir:

E10: "Hazırbulunuşluk konusunda ilk başladığımda öğrencilerimin durumu hiç iç açıcı değildi. Sayıları, alfabeyi vs. yeniden ögretmek durumunda kaldım. Nadiren de olsa aralarında ingilizce hazırbulunuşluğu iyi olan da vardı. Bu hazırbulunuşluğun kötü olmasının nedeni de çalıştığımı bölgede öğretmenlerin sık yer değiştirmesinden kaynaklıdır." (Yetersiz)

Hazırbulunuşluk seviyesini yeterli bulan E8 kodlu öğretmenin cevabı a şağıda örnek olarak verilmiştir.

E8: "Öğrencilerimizin hazırbulunuşlukları ölçme ve değerlendirme araçlarımızla baktığımız zaman yeterli düzeyde görünmektedir. Girmiş oldukları deneme sınavlarına baktığımızda, yaptıkları yazılılara da bakarak hazırbulunuşluklarının yeterli seviyede olduğunu söyleyebiliriz. Ayrıca öğrencilerin ingilizce öğretmenleri de değişmediği, aynı ögretmen tarafından yetiştirildikleri için dönüt-düzeltmeler daha rahat yapılmış ve hazırbulunuşlukları uygun seviyeye getirilmiştir." (Yeterli)

Tablo 9. Girdi boyutundaki 2. soruya ilişkin tema ve kodlar

\begin{tabular}{llc}
\hline Tema & Kod & Frekans(s) \\
\hline \multirow{2}{*}{ Öğrenciye uygunluk } & İçerik-yetenek uyumluluğu & $(4)$ \\
& İçerik-yetenek uyumsuzluğu & $(6)$ \\
\hline
\end{tabular}

Girdi boyutundaki ikinci soru olan "Programın içeriği öğrencilerin yetenekleri ile örtüşmekte midir?" kısmında "öğrenciye uygunluk" teması oluşturulmuştur. Bu soruda 6 öğretmen içerik ile yeteneğin uyumsuzluğunu; 4 öğretmen ise içerik ile yeteneğin uyumluluğunu belirtmiştir. Araştırmada yer alan öğretmenler bu soruya şu şekilde yanıtlar vermiştir:

K7: "Program içeriği öğrenci yetenekleri ile örtüşmüyor. Çünkü program öğrencilerin seviyesine göre çok üst düzeyde kallyor. Bu üst düzeyde kalma nedeniyle öğrenci derse ilgili-yetenekli bile olsa zorlanabiliyor." (içerik-yetenek uyumsuzluğu)

Programın içeriği ile öğrencilerin yeteneğinin uyumluluğunu belirten E8 ve E9 kodlu öğretmenlerin cevapları aşağıda örnek olarak verilmiştir.

E8: "Örtüşmektedir. Programımıza baktı̆̆ımız zaman diğer derslerle entegre olduğunu görüyoruz. Türkçe, Sosyal Bilgiler gibi derslerle de iç içe bir programımı bulunuyor. Bu derslerde gördüğü bazı kavramları ingilizce derslerinde de gördügünde yadırgamıyor. Bu 
da ögrrencilerin yeteneklerine dönük bir program içeriği olduğunu gösteriyor." (İçerikyetenek uyumluluğu)

Tablo 10.Girdi boyutundaki 3. soruya ilişkin tema ve kodlar

\begin{tabular}{llc}
\hline Tema & Kod & Frekans(s) \\
\hline \multirow{4}{*}{ Materyal Etkisi } & Başarıyı arttırma & $(10)$ \\
& Kalıcı öğrenme & $(4)$ \\
& Derse yönelik motivasyon & $(3)$ \\
& Öğrenci motivasyonu & $(3)$ \\
\hline
\end{tabular}

Girdi boyutundaki üçüncü soru olan "Farklı materyallerin öğrencilerin başarısı üzerinde etkileri nelerdir?" kısmında "materyal etkisi" teması oluşturulmuştur. Verilerden elde edilen kodlar: "başarıyı arttırma, kalııı öğrenme, derse yönelik motivasyon, öğrenci motivasyonu" şeklindedir. Araştırmada yer alan öğretmenler bu soruya şu şekilde yanıtlar vermiştir:

K1: "Derse materyal getirmek hem ögretmen hem de öğrenci için bir motivasyon sağlıyor. Bu bir gazete de olabilir bir broşür de. Bunlar daha kalıcı bir eğitim vermeyi sağlıyor. Ayrıca öğrenciler de bir sonraki ders için daha farklı bir beklentiye giriyor ve bu da sizin ögretmen olarak motivasyonunuzu arttırlyor. Olumlu ve motivasyonu arttırıcıdır." (Öğrenci motivasyonu, kalıcı öğrenme, derse yönelik motivasyon)

K7: "Öğrenci başarısına büyük etkisi bulunmaktadır. Örneğin görsel materyaller ve sesli materyallerle dersimi desteklemeye çalışıorum. Bu şekilde dersin ve ögrenmenin kalıclı̆̆ daha da artıyor. Böylelikle görsel ve işitsel zekâya da hitap edebiliyoruz." (Başarıyı arttırma, kalıı öğrenme)

Tablo 11. Girdi boyutundaki 4. soruya ilişkin tema ve kodlar

\begin{tabular}{llc}
\hline Tema & Kod & Frekans(s) \\
\hline \multirow{3}{*}{ Bireysel Çalışma } & Proje ödevleri & $(2)$ \\
& Derse katılım sağlama & $(2)$ \\
& Kelime analizi & $(3)$ \\
& Telaffuz çalışmaları & $(2)$ \\
\hline \multirow{4}{*}{ Toplu Çalışma } & Diyalog & $(3)$ \\
& Rol yaptırma & $(3)$ \\
& Grup çalışması & $(4)$ \\
& Partnerli çalışmalar & $(3)$ \\
\hline \multirow{3}{*}{ Ek Çalışmalar } & EBA içerikleri & $(2)$ \\
& Akıllı tahta & $(3)$ \\
& Yazılı materyaller & $(4)$ \\
& Ingilizce köşesi & $(3)$ \\
\hline
\end{tabular}

Girdi boyutundaki dördüncü soru olan "Çocukların dil becerilerini geliştirmek için sınıf içerisinde neler yapıyorsunuz?" kısmında "bireysel çalışma, toplu çalışma ve ek çalışmalar" temaları oluşturulmuştur. Bireysel çalışma temasından elde edilen kodlar: "derse katılımı sağlama, proje ödevleri, kelime analizi, telaffuz çalışmaları" şeklindedir. Toplu çalışma temasından elde edilen kodlar: "rol yaptırma, diyalog, grup çalışması, partnerli çalışmalar" şeklindedir. Ek çalışmalar temasından elde edilen kodlar "EBA içerikleri, akıllı tahta yazııı materyaller, İngilizce köşesi" şeklindedir. Araştırmada yer alan öğretmenler bu soruya şu şekilde yanıtlar vermiştir:

K3: " Bol bol dil becerisini kullanabilecekleri ortamlar yaratmaya çalş̧ıoruz. Sınıf mevcudu kalabalık olduğu için grup çalışması yapıyoruz. Onları baş başa bırakmakta zorlanıyoruz ama eşleştirmeler yapıyoruz, ikili eşmeler yapıyoruz yanında oturduğu kişi ile ya da arkasındaki kişiler ile bu dil becerisini geliștirebileceği ortamlar yaratmaya çalışıoruz ya da o dili kullanabilmesi öğrendikleri yapıyı pekiştirmek için yazılı 
materyaller ve proje ödevleri veriyoruz." (Proje ödevleri, derse katılım sağlama; grup çalışması, partnerli çalışmalar; yazılı materyaller)

K5: "Dil becerileri için çok nadirde olsa telaffuz çalışmaları yapıyoruz. Bazen sınıf içi diyalog yapıyoruz. Uygulamaya yönelik diyalog yapıyoruz. Başkada pek bir şey yapamıyoruz açıkçası sınıflar çok kalabalık olduğu için." (Telaffuz çalışmaları, diyalog)

Tablo 12. Girdi boyutundaki 5. soruya ilişkin tema ve kodlar

\begin{tabular}{llc}
\hline Tema & Kod & Frekans(s) \\
\hline & Ses dosyaları & $(1)$ \\
& Flash kart & $(4)$ \\
Görsel-İsitsel Araçlar & Akıllı tahta & $(6)$ \\
& Projeksiyon cihazı & $(1)$ \\
& Laptop & $(1)$ \\
& EBA içerik & $(3)$ \\
\hline Basıll-Yazılı Araçlar & Ders kitabı & $(5)$ \\
\hline
\end{tabular}

Girdi boyutundaki beşinci soru olan "Programda belirtilen materyallerin hangileri daha kullanışlıdır?" kısmında "görsel-işitsel araçlar ve basıı-yazııı araçlar" temaları çıkarılmıştır. Görsel işitsel araçlar temasından elde edilen kodlar: "akıllı tahta, EBA içerik, flash kart, ses dosyaları, projeksiyon cihazı, laptop; basılı yazılı araçlar temasından elde edilen kod: "ders kitabı" şeklindedir. Araştırmada yer alan öğretmenler bu soruya şu şekilde yanıtlar vermiştir:

K1: "Kitap çok kullanışlı değil. Ama EBA'da öğretmenler tarafından hazırlanmış materyaller var ya da kendi içeriğimi kendim yapıyorum. Kitaptaki en kullanışlı kısım ünite sonu değerlendirmeler denilebilir." (EBA içerik; ders kitabı)

E9: "En kullanışlısı akıllı tahtadır. Laptop ve projeksiyon cihazı kullanarak da iyi bir materyal hazırlayabiliyoruz. Sesli flash kartlar da büyük bir yarar sağlamaktadır." (Akıllı tahta, projeksiyon cihazı, laptop)

Araştırmanın girdi boyutunda görüşmecilerin verdikleri yanıtlara ve yanıtlardan çıkarılan kodlara göre "öğrencilerin hazırbulunuşluk seviyelerinin yetersiz olduğu; programın içeriğiyle öğrencilerin yeteneklerinin uyumsuz olduğu; materyal çeşitliliğinin öğrencilerin başarısını arttırdığı, kalıc öğrenme ve motivasyon sağladığı; öğretmenlerin dil becerisini geliştirmek için kelime analizi, grup çalışması, yazılı materyal kullanımı, akıllı tahta kullandığı; programdaki materyallerden akıllı tahta ve ders kitabının kullanışlı olduğu" ortaya çıkmıştır.

\section{3-Süreç Değerlendirmeye İlişkin Bulgular}

Araştırmanın süreç aşamasına ilişkin öğretmen görüşleri incelendiğinde programın işleyişi ile ilgili sorulara yanıt aranmış ve süreç boyutuna dair sorulan 3 soru neticesinde kodlara ulaşılmıştır, kodlar önceden belirlenen temalara yerleştirilmiştir. Süreç kısmında ulaşılan temalar "bilgiyi işleme, programın revizesi, uygulamada problem ve uygulamada çözüm" şeklinde listelenmiştir.

Elde edilen kodlar ve temalara bakarak 10 öğretmenin süreç değerlendirmeye yönelik görüşleri şu şekildedir.

Tablo 13. Süreç boyutundaki 1. soruya ilişkin tema ve kodlar

\begin{tabular}{llc}
\hline Tema & Kod & Frekans(s) \\
\hline \multirow{3}{*}{ Bilgiyi İşleme } & Transfer ve uygulama & $(3)$ \\
& Transfer & $(5)$ \\
& Uygulama & $(2)$ \\
\hline
\end{tabular}


Süreç boyutundaki ilk soru olan: "Öğrencilere bilgi sadece transfer mi ediliyor yoksa öğrenciler bilgiyi kullanıp uyguluyorlar mı?" kısmında elde edilen kodlara göre "transfer ve uygulama" 3 öğretmen, "transfer" 5 öğretmen, "uygulama" 2 öğretmen tarafından belirtilmiştir. Araştırmada yer alan öğretmenler bu soruya şu şekilde yanıtlar vermiştir:

K3: "Okulun bulunduğu konum ve şartlardan ötürü maalesef transfer düzeyinde kalıyoruz." (Transfer)

E8: "Biz öğrencilerimize anlatım tekniği ile bir şeyler verebileceğimizi düşünmüyoruz. Bu nedenle ögrrenci merkezli ders işleyerek, elimizden geldiğince öğrenci-öğrenci etkileşimi sağlayarak öğrencilerin bilgilerini daha kalıcı hale getirmesini sağlamaya çalışıyoruz." (Uygulama)

Tablo 14. Süreç boyutundaki 2. soruya ilişkin tema ve kodlar

\begin{tabular}{llc}
\hline Tema & Kod & Frekans(s) \\
\hline & Ders kitabının sadeleştirilmesi & $(6)$ \\
& Öğrenciye görelik ilkesi & $(2)$ \\
Programın Revizesi & Materyal çeşitliliği & $(5)$ \\
& Dil laboratuvarı & $(4)$ \\
& Ders saatini artırma & $(1)$ \\
\hline
\end{tabular}

Süreç boyutundaki ikinci soru olan: "Programda nasıl düzenlemeler yapılırsa öğrencilerin başarısı olumlu yönde etkilenir?" kısmında "programın revizesi" temasına ulaşımıştır. Elde edilen kodlara göre 6 öğretmen "ders kitabının sadeleştirilmesi", 3 öğretmen "materyal desteği" , 2 öğretmen "dil laboratuvarı", 2 öğretmen "Ingilizce konuşma" kodlarını belirtmiştir. Araştırmada yer alan öğretmenler bu soruya şu şekilde yanıtlar vermiştir:

K3: "Program açısından eleştirel bir yaklaşımım yok ama uygulama konusunda düzenlemeler olmalıdır mesela uygulama konusunda kitaplarımı iyileştirilirse materyallerin kalitesi arttırlıp ögrenci sayısı düzenlenirse ve dil sınıfı gibi bir ortam yaratllirsa program daha iyi hale gelir zaten iyi ama uygulama konusunda bizde sorun yaşamayız."(Ders kitabının sadeleștirilmesi, dil laboratuvarı)

K5: "Daha çok kitap dili olarak değil gündelik Ingilizce dili olarak değiştirilirse daha etkili olur. Yani kitapta makalede ya da herhangi bir kitaptaki dil değil de insanların günlük hayatta kullandıkları dile yönelik öğretim olursa öğrencilerin başarısının artacağını düşünüyorum." (Öğrenciye görelik ilkesi)

Tablo 15. Süreç boyutundaki 3. soruya ilişkin tema ve kodlar

\begin{tabular}{llc}
\hline Tema & Kod & Frekans(s) \\
\hline & Kitap içeriğinin yoğunluğu & $(2)$ \\
& Gelenekselci yaklaşım & $(2)$ \\
Uygulamada Problem & Ders saatinin yetersizliği & $(2)$ \\
& Derse yönelik önyargı & $(4)$ \\
& Kaynak yetersizliği & $(2)$ \\
\hline & Ders saatini artırma & $(2)$ \\
& Hayatilik ilkesine ağırlık & $(1)$ \\
& Kitabın sadeleştirilmesi & $(2)$ \\
& Derse hazırlık & $(2)$ \\
& Dil laboratuvarı & $(3)$ \\
& Yapılandırmacı yaklaşım & $(6)$ \\
& Materyal çeşitliliği & $(3)$ \\
\hline
\end{tabular}

Süreç boyutundaki üçüncü soru olan: "Programın uygulanmasında gördüğünüz problemler ve çözüm önerileriniz nelerdir?" kısmında 2 temaya ulaşılmıştır. Illk tema olan "uygulamada problem" kısmındaki kodlara göre 2 öğretmen "ders saati yetersizliği", 2 öğretmen 
"gelenekselci yaklaşım", 2 öğretmen "kitap içeriğinin yoğunluğu", 4 öğretmen "derse yönelik önyargı", 2 öğretmen "kaynak yetersizliği" kodlarını belirtmişstir. Araştırmada yer alan öğretmenler bu soruya şu şekilde yanıtlar vermiştir:

K2: "Sosyo-ekonomik düzeyi düşük bir okulda çalışmaktayım. Bundan dolayı buradaki çocuklara bununla ilgili materyaller sağlanmalı. Aynı şekilde ingilizce dersleri yeterli değil bundan dolayı ders saati arttırlabilir. Akılı tahtadan uygulamalar artırlabilir." (Ders saati yetersizliği)

E9: "Bilinenden bilinmeyene gitmiyoruz. Yakın çevremizle ilgili pek örnekler yok kitaplarımızda. Buluş yoluyla ögrenme etkinliklerine daha fazla yer verilirse daha iyi bir sonuç alınacaktır." (Gelenekselci yaklaşım)

İkinci tema olan" uygulamada çözüm" temasında 2 öğretmen "kitabın sadeleştirilmesi", 3 öğretmen "materyal çeşitliliği", 2 öğretmen "ders saati artırma", 1 "hayatilik ilkesine ağılık", 2 "öğretmen derse hazırlık", 3 öğretmen "dil laboratuvarı" 6 öğretmen "yapılandırmacı yaklaşım", 3 öğretmen "materyal çeşitliliği" kodlarıyla düşünce belirtmiştir. Araştırmada yer alan öğretmenler bu soruya şu şekilde yanıtlar vermiş̧tir:

K2: "Sosyo-ekonomik düzeyi düşük bir okulda çalısmaktayım. Bundan dolayı buradaki çocuklara bununla ilgili materyaller sağlanmalı. Aynı şekilde ingilizce dersleri yeterli değil bundan dolayı ders saati arttırlabilir. Akıllı tahtadan uygulamalar artırlabilir."(Ders saati artirma)

E6: "Bazen okuma metinleri çok yoğun metinler oluyor bu metinleri biraz daha sadeleştire bilirler bununla birlikte kitapta yer alan bazı kazanımları için uygulamalar yetersiz kalıyor. Bir de dinleme bölümlerinde çok sıkıntı yaşıyoruz dinleme bölümleri çocukların seviyelerine uygun değil daha basit daha sade ve biraz daha yavaş olması gerekir."(Kitabın sadeleştirilmesi)

Araştırmanın süreç boyutunda görüşmecilerin verdikleri yanıtlara ve yanıtlardan çıkarılan kodlara göre "bilgiyi uygulamaya kıyasla öğrencilere bilginin aktarıldığı, ders kitabının yoğun bilgiden arındırılarak sadeleştirilmesi gerektiği ve yapılandırmacı yaklaşıma daha çok yer verilmesi gerektiği" ortaya çıkmıştır.

\section{4-Ürün Değerlendirmeye iliş̧kin Bulgular}

Araştırmanın ürün aşamasına ilişkin öğretmen görüşleri incelendiğinde programın çıktıları ile ilgili sorulara yanıt aranmış ve ürün boyutuna dair sorulan 6 soru neticesinde 8 farklı temaya ulaşılmıştır. Ürün kısmında oluşturulan temalar "sınava hazırlık, hedeflere ulaşma, sınav başarısı, kelime bilgisi, dil gelişimi, sınıf içi uygulamalar, program açısından ders, yardımcı araçlar" şeklinde listelenmiştir. Elde edilen kodlar ve temalara bakarak 10 öğretmenin ürün değerlendirmeye yönelik görüşleri şu şekildedir.

Tablo 16. Ürün boyutundaki 1. soruya ilişkin tema ve kodlar

\begin{tabular}{llc}
\hline Tema & Kod & Frekans(s) \\
\hline Sınava Hazırlık & Yeterli & $(3)$ \\
& Yetersiz & $(5)$ \\
\hline
\end{tabular}

Ürün boyutundaki ilk soru olan: "Programın öğrencileri LGS' ye tam olarak hazırladığını düşünüyor musunuz?" kısmında "sınava hazırlık" temasına ulaşılmıştır. Elde edilen kodlara göre 2 öğretmen "yeterli", 8 öğretmen "yetersiz" olduğunu belirtilmiştir. Araştırmada yer alan öğretmenler bu soruya şu şekilde yanıtlar vermiş̧ir:

K1: "Hayır hazırlamıyor. Hem ders süresi kısa, hem sınıflar kalabalık. Mesela on tane soru var ama hepsi paragraf şeklinde ve bu da çok fazla kelime bilgisi gerektiriyor. Ama biz sinflarda bu kadar soru çözemiyoruz. Eski nesil sorularla kesinlikle hazırllyordu. Ancak şuanki sorularla kesinlikle hazırlamıyor." (Yetersiz) 
E8: "LGS sınavının ölçme değerlendirme açısından değerlendirdiğimizde zaten programa uygun biçimde tasarlandığını görürüz. Bu anlamda öğrenciler tamamen derste gördüğ̈̈ konulardan sorumlu oldukları için tam olarak hazırladığını düşünüyorum." (Yeterli)

Tablo 17. Ürün boyutundaki 2. soruya ilişkin tema ve kodlar

\begin{tabular}{llc}
\hline Tema & Kod & Frekans(s) \\
\hline Program amaçlarına ulaşma & Yeterli & $(4)$ \\
& Yetersiz & $(5)$ \\
\hline
\end{tabular}

Ürün boyutundaki ikinci soru olan: "Programın uygulanması sırasında hedeflenen amaçlara ulaşıldı mı?" kısmında "Program amaçlarına ulaşma" temasına ulaşılmışır. Elde edilen kodlara göre 4 öğretmen "yeterli", 5 öğretmen "yetersiz" kodlarını belirtmiştir. Araştırmada yer alan öğretmenler bu soruya şu şekilde yanıtlar vermiştir:

K7: "Ulaşılmadı. Görev yaptığımız şehrin (Şırnak) olanak eksikleri, teknoloji eksiklikleri, hazırbulunuşluk eksiklikleri nedenleriyle ulaşılamadı. Daha önce görev yaptığım İstanbul şehri içinde programın hedeflerine ulaşılamadığını söyleyebiliriz."(Yetersiz)

E10: "Öğrencilerin başarıları ile ölçeceksek başarı durumu gerçekten iyi, hedeflere ulaşabildik diyebiliriz. Çünkü gerçekten LGS sınavında ve yazılı sınavlarda başarılı sonuçlar aldığımızı görüyoruz. Okulumuz il genelinde ortalamada tüm okullar arasında 6. olmuştu." (Yeterli)

Tablo 18. Ürün boyutundaki 3. soruya ilişkin tema ve kodlar

\begin{tabular}{llc}
\hline Tema & Kod & Frekans(s) \\
\hline \multirow{4}{*}{ Sınav başarısı } & Düşük & $(6)$ \\
& Orta & $(3)$ \\
& Yüksek & $(1)$ \\
\hline
\end{tabular}

Ürün boyutundaki üçüncü soru olan: "Dönem sonunda yapılan LGS başarı durumlarını değerlendirir misiniz?" kısmında "sınav başarısı" temasına ulaşılmıştır. Elde edilen kodlara göre 6 öğretmen "düşük", 3 öğretmen "orta", 1 öğretmen "yüksek" kodlarını belirtmiştir. Araştırmada yer alan öğretmenler bu soruya şu şekilde yanıtlar vermiştir:

K7: "Bu konuda şöyle söyleyebiliriz: Derslere ilgili olan çocuklar genel olarak LGS Ingilizce kısmında başarılı olurlarken ilgili olmayan çocuklar ise başarılı olamadılar." (Orta)

E8: "Geçen dönemin LGS sonuçlarına baktığımız zaman öğrencilerimizin pek çoğu LGS sorularının 10 tanesinde 6-7 tanesi doğru yapabildi ve birkaç ögrencimiz de 1 yanlış geri kalanı tamamen doğru yaptı. Bu anlamda LGS başarı durumunda iyi durumda olduğumuzu rahatlıkla söyleriz." (Yüksek)

Tablo 19. Ürün boyutundaki 4. soruya ilişkin tema ve kodlar

\begin{tabular}{llc}
\hline Tema & Kod & Frekans(s) \\
\hline Kelime bilgisi & Yeterli & $(10)$ \\
\hline
\end{tabular}

Ürün boyutundaki dördüncü soru olan: "Program öğrencilerin kelime bilgisine katkı sağlamış mıdır?" kısmında "kelime bilgisi" temasına ulaşılmıştır. Elde edilen kodlara göre 10 öğretmen de "yeterli" kodunu belirtmiştir. Araştırmada yer alan öğretmenler bu soruya şu şekilde yanıtlar vermiştir:

E9: "Kitabın arkasında yer alan kelimeler oldukça yeterli düzeydedir. Zaten kitabın arkasındaki kelimelerin ünite içinde de sıkça kullanılması öğrencilerin kelime bilgisine katkı sağlamaktadır."(Yeterli) 
Tablo 20. Ürün boyutundaki 5. soruya ilişkin tema ve kodlar

\begin{tabular}{llc}
\hline Tema & Kod & Frekans(s) \\
\hline \multirow{2}{*}{ Dil gelişimi } & Düşük & $(1)$ \\
& Orta & $(2)$ \\
& Yüksek & $(7)$ \\
\hline
\end{tabular}

Ürün boyutundaki beşinci soru olan: "Dönem sonunda İngilizceye yönelik öğrencilerin gösterdiği gelişim nasıldır?" kısmında "dil gelişimi" temasına ulaşılmıştır. Elde edilen kodlara göre 1 öğretmen "düşük", 2 öğretmen "orta", 7 öğretmen "yüksek" kodlarını belirtmiştir. Araştırmada yer alan öğretmenler bu soruya şu şekilde yanıtlar vermiştir:

K5: "Dönem başına göre evet gelişim olur ama istenilen düzeyde hedeflenen düzeyde olmuyor maalesef. Her öğrenci için aynı şey söylenemiyor yani çok başarılı olan bir ögrrenci içinde tam olarak hedefe ulaştı̆ı̆ı ıöylenemez \%100 ulaşılmıyor hep bir şeyler eksik kalıyor." (Düşük)

E9: "En başarısız ögrencimiz dahi Ingilizce öğrenebileceğinin ve başarabileceğinin farkına vardı. Hiç Ingilizce kelime bilgisine sahip olmayan öğrencilerimiz bile yavaş yavaş ingilizce paragrafları okuyup anlayabilecek erişiye ulaştı. Genel anlamda bakacak olursak da büyük ilerlemeler kaydettiklerini söyleyebiliriz." (Yüksek)

Tablo 21. Ürün boyutundaki 6. soruya ilişkin tema ve kodlar

\begin{tabular}{llc}
\hline Tema & Kod & Frekans(s) \\
\hline & İngilizce konuşma & $(5)$ \\
& İdeal sınıf düzeni & $(4)$ \\
Sınıf içi uygulamalar & Dil laboratuvarı & $(4)$ \\
& Grup çalışması & $(6)$ \\
& Öğretmen rehberliği & $(4)$ \\
& Öğrenci aktifliği & $(2)$ \\
\hline \multirow{3}{*}{ Program açısından ders } & Grameri azaltma & $(1)$ \\
& 4 temel beceri & $(3)$ \\
& Öğrenciye görelik ilkesi & $(3)$ \\
\hline \multirow{4}{*}{ Yardımcı araçlar } & Materyal çeşitliliği & $(4)$ \\
& İnteraktif öğretim & $(7)$ \\
& İngilizce köşesi & $(1)$ \\
& Veli desteği & $(1)$ \\
\hline
\end{tabular}

Ürün boyutundaki son soru olan: "Ideal bir İngilizce dersi nasıl olmalıdır, bahseder misiniz?" kısmında 3 temaya ulaşılmıştır. İlk tema olan "sınıf içi uygulamalar" kısmındaki kodlara göre öğretmenler "Ingilizce konuşma, grup çalışması, ideal sınıf düzeni, dil laboratuvarı, öğretmen rehberliği, öğrenci aktifliği" kodlarını belirtmiştir. Araştırmada yer alan öğretmenler bu soruya şu şekilde yanıtlar vermiştir:

K1: "Daha çok karşllklı etkileşimin olduğu bir ders olmal. Gerçek materyallerle desteklenmiş olmalı. Hem öğretmen hem de öğrenci iletişimsel olmalı. Derste Türkçe konuşulmaması, çocukları maruz bırakmak açısından önemli. Farklı içerikler bulmak. Çocukları ana dili Ingilizce olan insanlarla buluşturmak da önemli. Gerekiyorsa kulıkklyafet de değiştirilebilir."(Ingilizce konuşma, öğrenci aktifliği)

K5: "Ideal bir Ingilizce dersi derse girildiğinde derste Ingilizce konuşmak olmalı ki çocuklar biraz dile maruz kalsın derse girildikten sonra böyle olmalıdır. Ben mesela derse girdim tüm ögretimi Ingilizce olarak yapabilirim flash kartlar kullanarak. Daha sonra bu kelimelerin telaffuzları üzerine çalışa bilirim telaffuzlar üzerine alıştırma yaparım ögrrencilerin telaffuzları öğrenmesi için sık sık tekrar yaptırırım daha sonra dinleme yaptıırım ve aslında kuralıda çocukların çıkarmasını isterim direk kendim vermem kuralı dinleme yaptırıp belirli yerleri tekrarlarım ve öğrencilere de tekrarladığım yerdeki farkı sorarım diğer dinledikleri yer ile kuralı kendileri de çıkardıktan sonra onlardan da örnekler isterim." (Ingilizce konuşma, öğretmen rehberliği, ögrrenci aktifliği) 
İkinci tema olan "program açısından ders" temasında öğretmenler, "4 temel beceri, öğrenciye görelik ilkesi, grameri azaltma" kodlarını belirtmiştir. Araştırmada yer alan öğretmenler bu soruya şu şekilde yanıtlar vermiştir:

K2: "Öğretmenin rehber olduğu öğrencinin aktif olduğu bir ders olmalı. Daha çok konuşmaya yönelik aktivitelerin olması gerekir. Öğrencilerin buna uygulaması gerekir, videolu anlatımlar olmalı, interaktif öğretimler uygulanmalı." (Öğrenciye görelik)

E10: "Öğretmenin rehber olduğu öğrencinin aktif olduğu bir ders olmall. Daha çok konuşmaya yönelik aktivitelerin olması gerekir. Ögrrencilerin buna uygulaması gerekir, videolu anlatımlar olmall, interaktif ögretimler uygulanmalı." (4 temel beceri)

Üçüncü tema olan "yardımcı araçlar" temasında öğretmenler "materyal çeşitliliği, interaktif öğretim, İngilizce köşesi, veli desteği" kodlarını belirtmiştir. Araştırmada yer alan öğretmenler bu soruya şu şekilde yanıtlar vermiş̧tir:

K3: "ideal bir İngilizce dersi öncelikle çok daha etkileşimli olmalıdır. Otuz kişi değil de maksimum on iki ögrrenci olmalıdır. Sıra düzeni çok önemlidir o etkileşimi sağlayacak şekilde olmalıdır ya ' $U$ ' düzeninde ya da çocukların birbirine dönük olabileceği herhangi bir düzende olmalıdır. Bol bol yüz yüze iletişim kurabilecekleri ve öğrendikleri kuralları kelimelere dökebilecekleri birbirleriyle çalışabilecekleri durumda olmalıdır ve tabi ki görsel, işitsel her türlü kaynaktan yararlanabileceğimiz bir ortam olmalıdır." (Materyal çeşitliliği)

E9: "Velilerin sürecin bir parçası hale getirilmesi gerektiğini düşünüyorum. Çünkü ödev yapmanın büyük bir önemi bulunuyor Ingilizce dersi için. Mümkün olduğu kadar bu derste öğretmenin Ingilizce konuşması gerektiğini düşünüyorum. Ingilizce dersinde sınıf düzeni belirlenirken ayrım yapılmamalı tüm öğrencilerin Ingilizce öğrenebileceği biçimde bir yer düzeni yapılmalıdır. Tüm okullarımızda da akıllı tahta, ingilizce köşesi gibi çeşitli materyallerle destekletilmelidir." (Veli desteği, Materyal çeşitliliği)

Araştırmanın ürün boyutunda görüşmecilerin verdikleri yanıtlara ve yanıtlardan çıkarılan kodlara göre: "Programın öğrencileri LGS'ye hazırlama konusunda yetersiz olduğu; programın uygulanması sırasında hedeflere ulaşmada yetersiz olduğu; öğrencilerin dönem sonunda girdikleri LGS'de başarılarının düşük olduğu; programın öğrencilere kelime bilgisi sağlama konusunda yeterli olduğu; dönem sonunda öğrencilerin İngilizce yönelik gösterdikleri gelişimin yüksek olduğu; ideal bir İngilizce dersinin interaktif öğretim, grup çalışması ve İngilizce konuşma ile işlenmesi gerektiği" ortaya çıkmıştır.

\section{TARTIŞMA, SONUÇ VE ÖNERILER}

Verilerin açıklanması ve anlamlandırılmasında araştırmaya destek olabilecek araştırmacının görüşleri, nitel araştırmada önemli bir konuma sahiptir. Bu sebeple araştırmacının; araştırmanın son aşamasında elde ettiği verilere anlam kazandırması ve bulgular arasındaki ilişkileri ortaya koyması, nedensellik ilişkisi kurması, bulgulara dayanarak sonuçlar elde etmesi ve bu sonuçların önemine yönelik açıklamalarda bulunması gerekmektedir (Yıldırım \& Şimşek, 2018). Bu bölümde araştırma sonucundaki bulgulara ilişkin tartışma, sonuç ve öneriler yer almaktadır.

\section{1-Bağlam Değerlendirmeye iliş̧kin Sonuçlar}

Araştırmanın bulguları irdelendiğinde İngilizce öğretmenlerinin bağlam boyutunda programın amaçlarıyla ilgili sınava hazırlamak ve 4 temel beceriyle birlikte İngilizce A2 seviyesini geliştirmek olduğu vurgulanmaktadır. Bunun yanında; öğrenciye uygun, 4 temel becerinin daha ağırlıkta olduğu ve etkileşimli eğitimin ağırlıklı olduğu bir programa intiyaç duyulduğu vurgulanmıştır. Güncellenen İngilizce Öğretim Programı́nda öğrencilerin, dil öğrencisi olmaktan çok dil kullanıcısı olmalarını sağlayabilmek için her türden sınıf etkileşimlerinde İngilizcenin kullanımı vurgulanmakta ve iletişimsel yeterliliğe özen gösterildiği belirtilmektedir. 8. Sınıf 
İngilizce Öğretim Programı́nın uygulanması durumunda ise öğrencilerin programda ulaşması beklenen hedefler, dinleme-anlama, sözlü etkileşim, sözlü anlatım, okuma-anlama, yazma becerileri şeklinde programda açıç̧a belirtilmiştir (MEB, 2018). Dinçer (2013)'de program amaçlarına yönelik öğretmenlerin farklı yanıtlar verdiğini orta koymuştur.

Programın beğenilen ve beğenilmeyen yönlerine yönelik öğretmenler farklı ifadeler söylemekle beraber bu ifadelerin yaklaşık yarısı programın beğenilen yönünün hayatilik ilkesine uygunluk, değerler eğitimi ve programın sadeliği olduğu yönündedir. 4 temel beceriye de yer verilmesi öğretmenler tarafından olumlu karşılanmıştır. Programın beğenilmeyen yönleri; uygulamanın yetersizliği, ders saatinin yetersizliği, program yoğunluğu, dil edinme yetersizliği şeklindedir. Demirtaş (2015)'ta benzer çalışmasında programın uygulanmasında en çok yaşanılan sıkıntıların ders saatinin yetersizliği ve ders kitabının mevcut programa uygun olmama durumudur. Bu soruna yönelik öğretmenlerin çözüm önerilerine bakıldığında ders saatlerinin arttıııması ve ders kitaplarının revize edilmesi gelmektedir. Dinçer (2013) 'de programın zayıf yönlerine yönelik dinleme-konuşma becerilerinin yetersizliğine değinmiştir. Programın içeriğinin dil becerisini geliştirme açısından yetersiz ancak sınava yönelik hazırlama açısından yeterli olduğu öğretmen görüşleri doğrultusunda tespit edilmiştir. Programda sınava hazırlık bir amaç olarak görülmediği halde 8. Sınıfların gireceği sınavdan dolayı öğretmenlerde böyle bir algı oluşmuştur. İngilizce Öğretim Programı ile ders kitaplarındaki içeriğin uyumlu olduğu belirtilmiştir. Ingilizce ders kitabı kazanımlarına bakıldığında program amaçlarıyla uyumu bu durumla örtüşmektedir. Aynı şekilde İngilizce ders kitap içeriğinin LGS'ye hazırlanan öğrencilerin seviyesine uygunluğu öğretmenler tarafından belirtilmiştir.

\section{2-Girdi Değerlendirmeye İlişkin Sonuçlar}

Araştırmanın bulguları irdelendiğinde İngilizce öğretmenlerinin girdi boyutunda öğrencilerin program için hazırbulunuşluk seviyelerinin yetersiz olduğu belirtilmiştir. Ancak benzer araştırmada Dinçer (2013), öğrencilerin kendileri ile ilgili olarak büyük oranda yüksek düzeyde bir hazırbulunuşlukta olduklarını belirtmişlerdir. Öğretmenler, öğrencilerin hazırbulunuşluk seviyesinin yetersiz olmasından dolayı program içeriğinin öğrencilerin yetenekleriyle örtüşmediğini belirtmiştir. Bundan kaynaklı sınıfta problemler yaşanmaktadır.

Öğretmenler farkı materyal kullanımının başarıyı arttırdığı, kalıcı öğrenmeyi ve motivasyonu arttırdığını belirtmiştir. Program amacına uygun olarak öğretmenler dil becerisini geliştirmek için sınıfta öğrenciyi aktif hale getirerek diyalog çalışmaları, grup çalışmaları ve çeşitlik etkinlikler düzenlediğini belirtmiştir. Işık (2008), bir yabancı dili öğrenmenin tek yolunun; öğrenmek istenilen dille ilgili zengin ve anlaşılabilir girdiye maruz kalmak ve öğrencilerin hem ders içi hem de ders dışı dile maruz kalacak ortam yaratmak olduğunu belirtmiştir. Yapılandırmacı yaklaşıma göre öğrenci, aktarılan bilgileri aynen kabul etmek yerine; yeni bilgileri önceki yaşantılarıyla harmanlayıp yorumlayabilmeli ve bilgiyi yapılandırabilmelidir (Güven, 2008). Öğretmen ise rehber bir konumda bulunmalı ve 4 temel dil beceri gelişimini destekleyici tarzda sürece rehberlik etmelidir. Yapılandırmacı öğrenme ortamlarında uygulanabilecek uygun stratejiler; buluş yoluyla, araştırma ve incelemeye dayalı, işbirlikli öğretim stratejileridir (Turan \& Sayek, 2006). Öğretmenler programda belirtilen materyallerden akıllı tahta, ders kitabı, teknolojik dokümanlar ve flash kartların daha kullanışlı olduğunu belirtmiştir. Yapılandırmacı öğrenmede sınıfta kullanılması için bazı araç-gereçler önerilmiştir. Bunlardan özellikle İngilizce öğretimiyle ilgili olanlar; sınıf ortamında kullanılabilecek nesneler, afişler, eğitici filmler, slaytlar, TV ve radyo programları şeklindedir (Uşun, 2007). Dil öğrenmeyi kolaylaştırıp öğrencilerin bilgi sahibi olmalarında bu tür görsel, işitsel ve basılı-yazılı materyallerin kullanımı önemlidir. Materyal imkânsızlığı olan bölgelerde ise aynı durum söz konusu olmamaktadır. 


\section{3-Süreç Değerlendirmeye illişkin Sonuçlar}

Araştırmanın süreç değerlendirme kısmına ilişkin sonuçlara bakıldığında öğretmenler, öğrencilere bilginin genelde transfer edildiğini sınıfa göre hem transfer hem de uygulamanın da gerçekleştiğini belirtmiştir. Aynı zamanda ders kitabının sadeleştirilmesini isterken bunun yanında materyal çeşitliliği ve dil laboratuvarına da vurgu yapılmıştır. Yabancı dil dersleri, kendi yaklaşımları gereği daha fazla materyal kullanılmasını gerektirmekte ve dil öğrenimini görsel ve işitsel teknoloji araçlarıyla desteklenilmesini zorunlu kılmaktadır (Kartal, 2005). Materyal çeşitliliği ve dil laboratuvarı okula ve öğretmene göre esnek olduğu halde görüşmecilerin bu yorumu yapmalarının nedeni öğretim programını sınıf ile bütünsel değerlendirmelerinden kaynaklanmaktadır.

Öğretmenlere göre programın uygulanmasında görülen problemler içerisinde, derse yönelik bir önyargı bulunduğu belirtilmiştir. Günümüzde İngilizce dersi öğrencileri arasında dil öğrenme sürecine dair önyargılar bulunması, bugün halen İngilizce dersinin Türkiyede öğrenilmesini zorlaştıran etkenler arasında yer almaktadır (Yaman, 2018). Öğrencilerin önyargısının İngilizcenin öğrenilmesi zor bir ders olduğu ve hayatlarında nerede kullanacaklarını bilmedikleri öğretmenler tarafından ortaya koyulmuştur. Yine program uygulanmasında görülen problemler kısmında ders saati yetersizliği, kaynak yetersizliği, gelenekselci yaklaşım sorunları da vurgulanmıştır.

Türkiye'de yabancı dil eğitim programı incelendiğinde 2012-2013 eğitim-öğretim yılından beri 8. sınıf düzeyinde dört saat yabancı dil dersi verdiği görülmektedir. Milli Eğitim Bakanlığı ve uzmanlara göre bu süre dil öğrenmek için yeterli görülmemektedir (ERG., 2018). Görüşmeci öğretmenler uygulamada çözüm kısmında verilen yanıtlarda özellikle yapılandırmacı yaklaşım üzerinde durmuş, materyal çeşitliliği ve dil laboratuvarının çözüm oluşturacağı burada da vurgulanmıştır. Görüşmecilerin, programın uygulanmasında gördükleri sorun kısmında belirttikleri gelenekselci yaklaşım ve programın uygulanmasına önerdikleri çözümde yapılandırmacı yaklaşımın önerilmesinin aslında her ne kadar İngilizce öğretim programı yapılandırmacı yaklaşıma göre tasarlanmış olsa da öğretmenlerin gelenekselci yaklaşımda olduklarını göstermektedir. Öğretmenlerin aldıkları eğitimsel temellerin, kendi öğretim süreçlerinde yeterlik algılarını (Çapri \& Çelikkaleli, 2008), bu yeterlik algılarının da öğretim sırasında gerçekleştirmiş oldukları eğitsel etkinlikleri etkilediği belirtilmektedir (Gelbal \& Kelecioğlu, 2007).

\section{4-Ürün Değerlendirmeye ilişskin Sonuçlar}

Araştırmanın ürün değerlendirme kısmına ilişkin sonuçlara bakıldığında öğretmenlere göre programın öğrencileri LGS'ye hazırlamada yetersiz kaldığı yorumuna ulaşılabilir. Amaçlanan hedefler konusunda öğretmenler, programın amaçlanan hedeflere ulaşma konusunda yetersiz olduğunu belirtmişlerdir. Ayrıca öğrencilerin dönem sonunda girmiş oldukları LGS'ye dair başarılarının düşük olduğu da vurgulanmıştır. Ancak programın dil becerileri noktasında öğrencilerin kelime bilgisine katkı sağlamış olduğu belirtilmiştir. Öğrencilerin dönem sonunda göstermiş oldukları gelişimin yüksek olduğu da öğretmenler tarafından vurgulanmıştır. İdeal bir İngilizce dersi için sınıfta İngilizce konuşmaya daha fazla yer ayrılması gerektiği, interaktif eğitime yer verilmesi gerektiği, grup çalışmalarına daha çok yer verilmesi gerektiği bunların yanında dil laboratuvarı ve öğretmen rehberliğinin de yapılması gerektiği ortaya koyulmuştur. İdeal bir sınıf ortamı sağlandığında daha başarılı sonuçlar alınacaktır.

Araştırmanın sonucuna bakıldığında öğretmenlerin, programın amaçlarından olan 4 temel dil becerisini geliştirebilecek nitelikte olduğuna yönelik öğrencilere duydukları inancın 
çoğunlukla olumsuz olduğu sonucuna ulaşıımıştır. Okul çevresinin ve okul şartlarının iyi veya kötü ne olursa olsun uygun ortam ve imkânlar sağlandığında, öğrenciyi motive edecek bir ortam yaratıldığında ve gerekli materyallerle desteklendiğinde her öğrencinin İngilizceyi öğrenebileceği ve başarının artabileceği söylenebilir. Ayrıca öğretmenlerin her okulda mutlaka bir dil laboratuvarı bulunması konusunda beklentide oldukları da söylenilebilir. Yabancı dil öğretiminin ülkemizde sağlıklı bir biçimde gerçekleştiğini söylemek zordur. Bunun nedeni yabancı dil derslerinde kullanılan materyaller, ders kitapları ve okulun fiziki olanaklarının yetersizliğidir (Doğan, 2009). Öğrencilerin İngilizce öğrenme konusunda yaşantı eksiklerini belirten öğretmenlere göre en azından İngilizce derslerinde öğretmenlerin tamamen İngilizce konuşarak öğrencilerin yaşantı eksiklerinin giderilebileceği yorumuna da ulaşılabilir. Programda öğrencinin etkin rol almasını, hedeflenen dilin becerilerini geliştirip kendi yaşamında kullanmasını, dili iletişim için bir araç haline getirebilmesini benimsediği vurgulanmıştır (Demir \& Yavuz, 2014).

\section{Öneriler}

Araştırmaya katılan öğretmenlerden gelen ve çalışma sonunda elde edilen bulgular ışığında araştırmacılar tarafından geliştirilen birtakım öneriler olmuştur. Bu öneriler aşağıda maddeler halinde sıralanmıştır:

- Programda Liseye Geçiş Sınavı (LGS)'nın varlığından söz edilmemiş, ancak öğretmenler sınava hazırlamayı amaç olarak görmüştür. 8. Sınıflar sınava gireceği için programda belirtilen dil becerisini geliştirme amacı tam olarak gerçekleşememektedir. Bu açıdan programın amaçlarının netleşmesi ve bu doğrultuda revize edilmesi önerilebilir.

- Program içeriği ve ders saatleri tekrar gözden geçirilerek revize edilmesi önerilmektedir.

- Programın etkili uygulanabilmesi için sınıf mevcutlarının düzenlenmesi, haftada 4 saat olan İngilizce ders saatinin artırılması gerekmektedir. Aynı şekilde gizil öğrenme ortamlarının arttıııması bu doğrultuda dil sınıfları oluşturulmalısı sağlanabilir.

- Sosyo-ekonomik düzeyi düşük olan okullarda fırsat eşitliğini sağlamak için aynı şartları sağlamak için çalışmalar, projeler yürütülmelidir. Okullar arası materyal paylaşım alanları yaratılmalı bunun için eTwinning tarzı projeler yaratılabilir.

- Yapılan araştırma, 8. sınıf İngilizce programı CIPP Model esas alınarak öğretmen görüşleri açısından değerlendirilen özgün bir çalışmadır. Bu sürece öğrencilerin görüşleri de alınıp araştırma kapsamı genişletilebilir. Farklı program değerlendirme modelleri kullanılabilir.

- Çalışmanın sadece Gaziantep ve Şırnak'ta görevli öğretmenler ile sınırlı olmasından dolayı, konuyla ilgili çalışmaların daha geniş örneklem grubuyla ve farklı illerde yapılması önerilmektedir.

- Öğretmenlerin derslerini işlerken farklı materyal kullanabilmeleri için buna yönelik kazanımların ve etkinliklerin düzenlenmesi önerilmektedir.

- Öğretmenlerin belirttiği görüşlere göre; öğrencilerin pek çoğunun program için hazır bulunuşluk düzeyinin yetersiz olmasından kaynaklı sorunlar ortaya çıkmaktadır. Bu nedenle öğrencilere İngilizce dilinde daha fazla öğrenme yaşantısı sunacak etkinliklere yer verilmesi önerilmektedir. 


\section{KAYNAKÇA}

Akman, G. (2014). Nicel ve nitel araştırma yöntemleri. Afyon Kocatepe Üniversitesi, Çay Meslek Yüksekokul, İşletme Yönetimi Programı, Yönetim ve Organizasyon Bölümü.

Broghton, G., Brumfit, C., Flavell, R., Hill, P., \& Pincas, A. (2003). Teaching English as a foreign language (2. b.). London: Routledge.

Büyüköztürk, Ş., Çakmak, E., Akgün, Ö., Karadeniz, Ş., \& Demirel, F. (2010). Bilimsel araştırma yöntemleri. Ankara: Pegem Yayınevi.

Çapri, B. ve Çelikkaleli, Ö. (2008). Öğretmen adaylarının öğretmenliğe ilişkin tutum ve mesleki yeterlik inançlarının cinsiyet program ve fakültelerine göre incelenmesi. Inönü Üniversitesi Eğitim Fakültesi Dergisi, 9(15), 33-53.

Demir, Y. ve Yavuz, M. (2014). Finlandiya, Japonya, Kore, Çin (Şangay) ve Türkiye'deki İngilizce dersi öğretim programlarının karşılaştııılmalı olarak incelenmesi. Mediterranean Journal of Humanitie, 4(1), 115 128.

Demirel, Ö. (2005). Avrupa Konseyi dil projesi ve Türkiye uygulaması. Milli Eğitim Dergisi(33), 167.

Demirtaş, Z., \& Erdem, S. (2015). 5. sınıf ingilizce dersi öğretim programı: Güncellenen programın bir önceki programla karşılaştırılması ve programa ilişkin öğretmen görüşleri. Sakarya University Journal of Education, 5(2), 55-80.

Dinçer, B. (2013). 7. sınıf ingilizce öğretim programının Stufflebeam'in bağlam-girdi-süreç-ürün (CIPP) modeline göre değerlendirilmesi. (Doktora Tezi),. Adnan Menderes Üniversitesi Sosyal Bilimler Enstitüsü. Aydın.

Doğan, İ. (2009). İngilizce öğretmenlerinin mesleki yeterlilik algıları ve Ingilizce öğretiminde karşılaştıkları sorunlar. (Yayımlanmamış Yüksek Lisans Tezi). Yeditepe Üniversitesi Sosyal Bilimler Enstitüsü. İstanbul.

Erden, M. (1998). Eğitimde program değerlendirme. Ankara: Anı Yayıncılık.

ERG. (2018). Eğitim izleme raporu. http://www.egitimreformugirisimi.org/wpcontent/uploads/2017/03/EIR_2017_2018_29.11.18.pdf adresinden 10 Ekim 2020 tarihinde erişilmiştir.

Gelbal, S. ve Kelecioğlu, H. (2007). Öğretmenlerin ölçme ve değerlendirme yöntemleri hakkındaki yeterlik algıları ve karşılaştıkları sorunlar. Hacettepe Üniversitesi Eğitim Fakültesi Dergisi, 33(33), 135-145.

Güven, S. (2008). Sını öğretmenlerinin yeni ilköğretim ders programlarının uygulanmasına ilişkin görüşleri. Milli Eğitim Dergisi, 36(177), 224-236.

Işık, A. (2008). Yabancı dil eğitimimizdeki yanlışlıklar nereden kaynaklanıyor? Journal of Language and Linguistic Studies, 4(2), 15-26.

Kapcak, B. C., \& Okuyan, F. (2016). Nitel araştırmada geçerlilik ve güvenirlik. (Yayınlanmamış Yüksek Lisans Tezi). Adnan Menderes Üniversitesi Sosyal Bilimler Enstitüsü. Eğitim Bilimleri Anabilim Dalı. Aydın.

Kartal, E. (2005). Bilişim-iletişim teknolojileri ve dil öğretim endüstrisi. The Turkish Online Journal of Educational Technology - TOJET, 4(4), 82-87.

Kelly, A. (2004). The curriculum theory and practice. London: Sage Publication Limited.

Krefting, L. (1991). Nitel araştırmada titizlik: Güvenilirliğin değerlendirilmesi. Amerikan Mesleki Terapi Dergisi, 45(3), 214-22.

Kuş, E. (2003). Sosyal bilimlerde araştırma teknikleri nitel mi, nicel mi? . Ankara: Anı Yayıncılık.

MEB. (2018). Ingilizce Dersi Öğretim Programı. Ankara.

Miles, M., \& Huberman, A. (1994). Qualitative data analiysis (second edition). London: Sage Publication.

Peker, T. (2006, Eylül). Çal bölgesindeki okullarda Ingilizce ögretiminin sorunları ve çözüm. Çal Sempozyumu'nda sunulmuş bildiri (s. 684-690). Denizli.

Robinson, B. (2002). The CIPP approach to evaluation. Collit Projekt. A Backgroud Note.

Robson, C. (1993). Robson C. (1993) Real world research. A Resource for Social Scientists and PractitionerResearchers. Oxford: Blackwell Publishers.

Saracaloğlu, A. S. (1995). Üniversite öğrencilerinin yabancı dile yönelik tutumları. Eğitim Fakültesi Eğitim Bilimleri Dergisi, 73-92.

Stufflebeam, D. L. (2003). The CIPP Model of evaluation. T. Kelllaghan, \& D. Stufflebeam D.S. (Eds). International Handbook of Educational Evaluation (31-62). Great Britian: Dordrech: Kluwer Academic.

Turan, S., \& Sayek, İ. (2006). Tıp eğitiminde öğrenen merkezli yaklaşımlar. Hacettepe Tıp Dergisi , 37(3), 171-175.

Türnüklü, A. (2000). Eğitimbilim araştırmalarında etkin olarak kullanılabilecek nitel bir araştırma tekniği: görüşme. Kuram ve Uygulamada Eğitim Yönetimi Dergisi. 6(4), 543-559. 
Uşun, S. (2007). Yapılandırmacı program geliştirme süreçlerinde eğitim durumu düzenleme öğeleri ve ilkeleri. 16. Ulusal Eğitim Bilimleri Kongresi (05-7 Eylül 2007). Gaziosmanpaşa Üniversitesi, Eğitim Fakültesi. Tokat.

Yaman, İ. (2018). Türkiye'de İngilizce öğrenmek: Zorluklar ve fırsatlar. Rumelide Dil ve Edebiyat Araştırmaları Dergisi, 11, 161-175.

Yıldırım, A. ve Şimşek, H. (2005). Sosyal bilimlerde nitel araştırma yöntemleri. Ankara: Seçkin Yayıncllık. Yıldırım, A., ve Şimşek, H. (2018). Sosyal bilimlerde nitel araştırma yöntemleri. Ankara: Seçkin Yayıncılık. Yin, R. (2003). Case study research design and methods. Thousand Oaks,: CA: Sage.

Yücel, E., Dimici, K., Yıldız, B., \& Bümen, N. (2017). Son 15 yılda yayımlanan ilk ve ortaöğretim İngilizce dersi öğretim programları üzerine bir analiz. Ege Eğitim Dergisi, 18(2), 702-737. 


\section{Evaluation of 8th Grade English Language Curriculum According to Context, Input, Process and Product (CIPP) Model}

\author{
Dr. Mehmet Başaran (Academic) \\ Gaziantep University-Türkiye \\ mehmetbasaran@outlook.com
}

\author{
Oğuzhan ilteriş Özdemir \\ Ministry of National Education \\ bilgehaniltekin@gmail.com
}

\author{
Muhammed Salih Can \\ Ministry of National Education \\ salih.dorian02@gmail.com
}

\begin{abstract}
The main aim of this research is to evaluate the eighth grade English curriculum of secondary education, which has been carried out since the academic year 20182019, in line with the opinions of the teachers by using the context-input-processproduct (CIPP) model developed by Stufflebeam. In the study, a case study was applied, which is one of the qualitative research methods. The study group of the research consists of 8th grade English teachers working in Gaziantep and Şırnak Provinces, which are determined by using criterion sampling method, which is one of the purposive sampling method. Qualitative data were obtained through structured interview forms based on the CIPP Model. Descriptive analysis method was used in analyzing qualitative data. The research group consists of 8th grade English teachers working in Gaziantep and Şırnak. The qualitative data were collected through structured interview forms based on the CIPP Model. In the analysis of qualitative data, descriptive analysis method was used. In order to evaluate the program from various perspectives and to provide a holistic framework, to obtain valuable data it is important to carry out the evaluation study by adapting it to the CIPP Model. Context evaluation results; The teachers stated that the program aims were to improve the language skills and to prepare for the exam. In the program, preparing for the exam is not specified as an aim. Results regarding input evaluation; it was observed that teachers' views especially on materials were negative and for many reasons they were insufficient to meet the objectives of the program. Process evaluation results; In the process, it was observed that some problems such as program intensity, classroom environment, insufficient class hours, level differences between students and bias towards the course were experienced. Results related to product evaluation; The program was found to be insufficient in reaching the intended targets, but it contributed to the vocabulary. The results of the research revealed that the program needed revision in theory.
\end{abstract}

Keywords: English Curriculum, CIPP Model, Program Evaluation

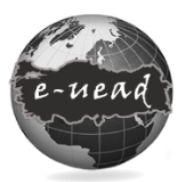

E-International Journal of Educational Research, Vol: 11, No: 3, 2020, pp.154-178

DOI: 10.19160/ijer.767692

\section{Suggested Citation:}

Başaran, M. Özdemir, O.I., \&. Can, M. S. (2020). Evaluation of 8th Grade English Language Curriculum According to Context, Input, Process and Product (CIPP) Model. E-Uluslararası Eğitim Araştırmaları Dergisi, Cilt: 11, Sayı: 3, 2020, ss. 154-178, DOI: 10.19160/ijer.767692 


\section{EXTENDED ABSTRACT}

Problem: Today, as a result of technological advances, people have established more intensive relationships between people, people around the world have become close to each other thanks to mass media and relationships have been established in different fields. Therefore, the need for language has increased over time. Foreign language today; It means knowing the technologies, arts, sciences and cultures of different nations and communicating in every field. The fact that English is active in the field of science has made English the most important communication language in terms of accessing information in the 21st century compared to other languages. In today's world, the need for language with foreign language lessons is tried to be fulfilled in both public and private schools. English Teaching Program in Turkey is re-organized in line with the overall objectives of the National Education and its need has been attempted to meet. In order to provide primary and secondary school students high quality English education in Turkey and of course for the continuation of a current curriculum subjects must be revised continuously. In order to ensure that students become active language users, the use of English in all kinds of classroom interactions is emphasized and care is taken to establish a certain level of communication. 8. specified Education Program in Turkey, which corresponds to A2 level. This level aims to develop students in the area of listening, speaking, reading and writing skills.

In this study, it is aimed to evaluate in line with the opinions of teachers by using the Context - Input - Process - Product (CIPP) Model of the 8th Grade English Teaching Program of the Secondary Education, which has been running since 2018-2019 academic year. While evaluating the program, it is tried to find out to what extent the program has achieved the specified goals or what deficiencies in the program. If a program is to be evaluated, it must be based on the program evaluation approach and model. It is important to evaluate the program from various perspectives and to adapt the program to the CIPP Model in terms of obtaining valuable data and in terms of creating a holistic framework.

Method: In this research, a qualitative research method, which examines the opinions of English teachers about the 8th Grade English Curriculum based on the Context-Input- Process- Product (CIPP) Model, was used. Since the opinions of 10 English teachers about the 8th Grade English Curriculum were revealed in the study, the design of the study was determined as a case study. In this research, the study group was determined using the criterion sampling method, one of the purposeful sampling methods. The study group of the research consists of 10 English teachers who attended 8th grade English lessons in Gaziantep and Şırnak who have worked at schools under the Ministry of National Education for at least two years. This study group was selected due to its accordance with the criteria determined by the researchers beforehand. In order to ensure validity and reliability, participants were selected from volunteer teachers, and the researcher trilogy technique and expert opinion were used during the evaluation of the data.

Qualitative data was collected through structured interview forms based on the CIPP Model. The low number of participants and the ability of the participant to express his / her thoughts sincerely during the interview was effective in choosing this type of interview. Descriptive analysis method was used in the analysis of qualitative data. In the interview, open-ended questions were asked to the participants according to the predetermined themes. Codes were obtained from the answers given to the questions. The data obtained were analyzed by the researchers at different times. The researchers then compared their analysis and identified the points reached and reached the consensus. The researchers used the formula "Reliability = Consensus / Disagreement + Consensus x 100" developed by Miles and Huberman (1994) to finalize their analysis. Coherence reliability was found as 82 among the researchers. 
Findings: The results of the research are considered as the 4 steps of the CIPP model as context, input, process and product evaluation. In the context assessment section, which is the first step, English teachers; He emphasized on developing A2 level, preparing for 4 basic skills and exam. In addition, the use of English and communication competence were also emphasized by teachers. In addition to being compatible with the program objectives of the textbook, English teachers also stated that the textbook content is appropriate for the level of students preparing for LGS.

In the input evaluation section, which is the second step, the level of student readiness is insufficient in the program. In addition, the use of materials increases academic success, ensures permanent learning and increases motivation. While the teachers stated that the smart board, textbook, technological documents and flash cards were useful from the materials specified in the program, they also suggested real objects, posters, bulletins, educational films, TV and radio programs that can be used in the course related to teaching English.

In the process evaluation section, which is the third step, teachers stated that the knowledge was mainly transferred to the students and that they had the opportunity to transfer and apply it in some classes. Teachers responded to the problems they encountered in the implementation of the program, such as prejudice towards the lesson, lack of lesson hours, and traditionalist approach. As a solution to the program, solutions such as constructivist approach, material diversity and language laboratory were offered.

As a last step, in the product evaluation section, teachers commented that the program was insufficient in preparing students for LGS and inadequate in reaching the intended goals. Teachers made suggestions such as giving more place to speak English for an ideal English lesson, language lab, teacher guidance and group work. The teachers emphasized that there is a lack of experience in learning English and that this deficiency can be overcome by the student taking an active role, developing the targeted language skills and using them in his own life and making the language a communication tool.

Suggestions: In light of the findings obtained during the research, some points that need to be corrected or changed in terms of the program have been reached and suggestions have been compiled. Although the program does not adopt it as a goal, the Transition to High School Exam, which is important for students, was seen by teachers as a goal and it was suggested that the program should be revised accordingly. It may be suggested that the content of the program should be rearranged in accordance with the opinions of the teachers and the number of lessons should be increased. It can be suggested that students' language level should be determined and learning environments should be created by having fun. It is also suggested that a more comprehensive study involving more crowded study groups and different provinces should be carried out due to the limited application of the study to teachers in 2 cities as Sirnak and Gaziantep. 